\title{
OPEN Mineralogy and Stable Isotopes of Tetradymite from the Dashuigou Tellurium Deposit, Tibet Plateau, Southwest China
}

\begin{abstract}
Jianzhao Yin ${ }^{1 *} \&$ Hongyun Shi $^{2}$
Due to the very limited quantity of associated tetradymite, both mineralogical and geochemical research on tetradymite is scarce and incomplete. By taking advantage of the discovery of the Dashuigou tellurium deposit in Tibet Plateau, the authors conducted mineralogical studies on tetradymite. The authors present new mineralogical data including reflectance, micro-pressure hardness, chemical compositions focusing on its chemical formula $\mathrm{Bi}_{2.00} \mathrm{Te}_{1.89} \mathrm{~S}_{0.95 \sim 1.00}$, unit cell parameters $(a=4.239 \AA, c=29.595 \AA)$ and lattice parameters $\left(a=10.172 \AA, v=154.391 \AA^{3}\right)$, pyroelectricity ( $\mathrm{N}$ type), and stable isotopes including sulfur and lead. The authors find that: $\delta^{34} \mathrm{~S} \% 0$ of tetradymite varies between $-0.5 \sim 2.1$ with a 15 -sample average of 0.56 , similar to that of meteorites and rocks from the mantle, indicating that the sulfur is from the mantle; lead isotopes of the tetradymite formed in the late metallogenic epoch is different from that of both pyrite and pyrrhotite formed in the early metallogenic epoch, further indicating that the three minerals formed in different metallogenic epochs; lead isotope compositions reveal that tellurium ore bodies emplaced in a quick process mainly in the form of ore magma; lead of the deposit is primarily from the mantle with some captured from the Earth's crust. These findings help fill in large gaps of information for the mineral tetradymite.
\end{abstract}

Tellurium ( $\mathrm{Te}$ ) is usually categorized as a scattered or dispersed element (abbreviated as SM). SM are those metals, semimetals and/or nonmetals that have similar geochemical characteristics with Clark values too low to enrich into independent deposits, but that play very important roles in modern science, industry, national defense and the frontiers of technology. It is thought in the traditional theory of mineral deposits and geochemistry that Te could not form independent deposits, but only exist as associated components in other metallic deposits. The abundance of Te in the Earth's Crust is very low. According to $\mathrm{Li}^{1}$, the average content of Te in the Earth's crust is $2.0 \times 10^{-8}$ in China, and only $1.34 \times 10^{-9}$ worldwide.

At present, the world's supply of refined tellurium is mainly recovered from Te-bearing minerals including pyrite, sphalerite, chalcopyrite, galena, pyrrhotite, volcanogenetic sulfur, bismuthinite, arsenopyrite, and cassiterite, etc. Generally speaking, only sulfide ores containing more than $0.002 \%$ Te can be used. As a result, the amount of refined tellurium that can be recovered is very limited. Most of the recoverable Te in the world is from copper deposits, and it is estimated that only $0.065 \mathrm{~kg}$ of Te can be produced in the refining process of one ton of copper ${ }^{2,3}$.

\section{Regional Geological Setting}

The Dashuigou tellurium deposit is located in the transitional belt between the Yangtze Platform and Songpan-Ganzi folded belt, as part of the Tibetan Plateau (Fig. 1). The deposit is nestled in the convergence between the Indian, Eurasian and Pacific Plates. The crust-mantle structures and properties in the region are the result of tectogenesis throughout various geological times. It implies the turning boundary of the Earth's crust's thickness. It is also a gravity gradient zone which controls not only the production and development of earthquakes and tectonomagmatic events, but also the distribution of a series of mineral deposits. Geophysical data 


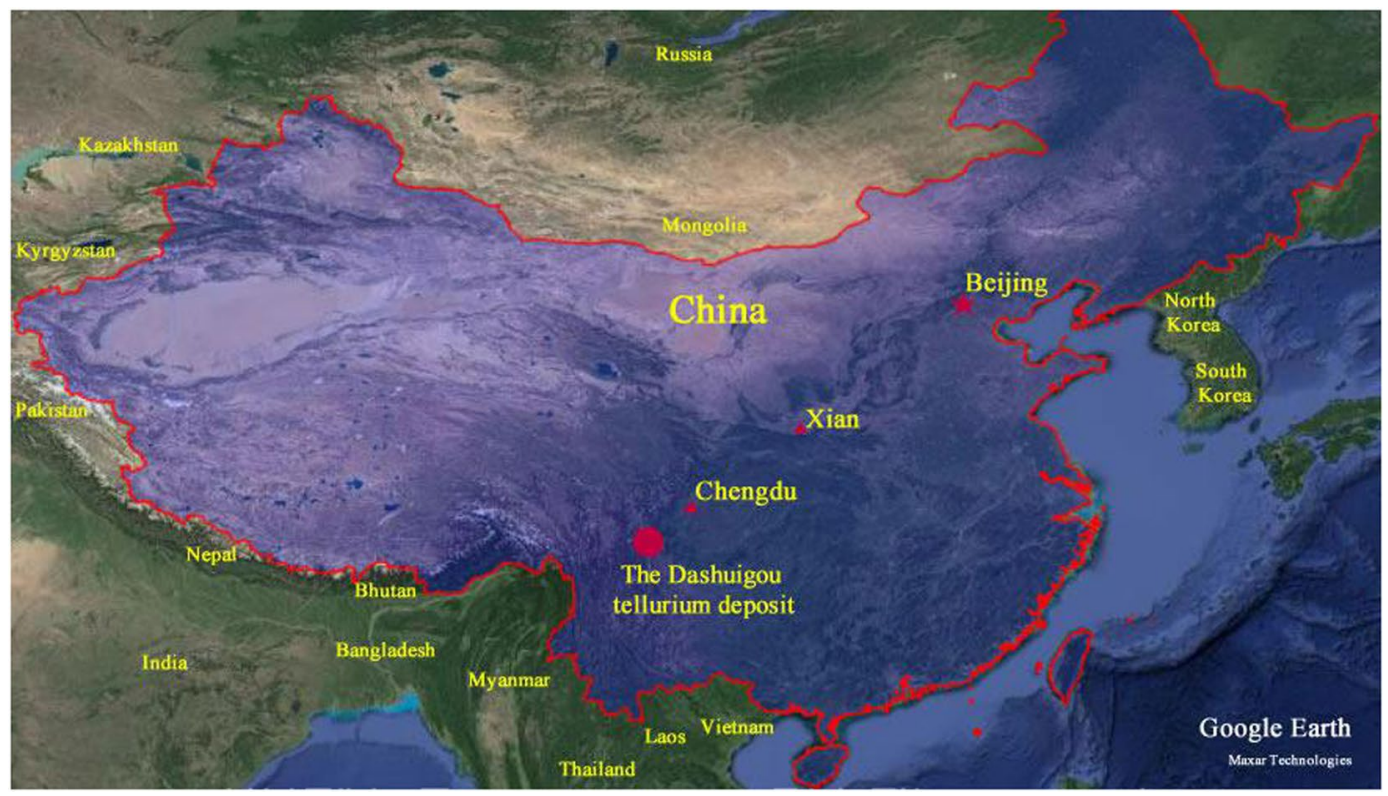

Figure 1. Location map of the dashuigou tellurium deposit. (Google Earth 7.1.8.3036 (32-bit): http://download. pchome.net/industry/geography/detail-20351.html, and 91 v17.5.8: www.91weitu.com; accessed January 25-27, 2020).

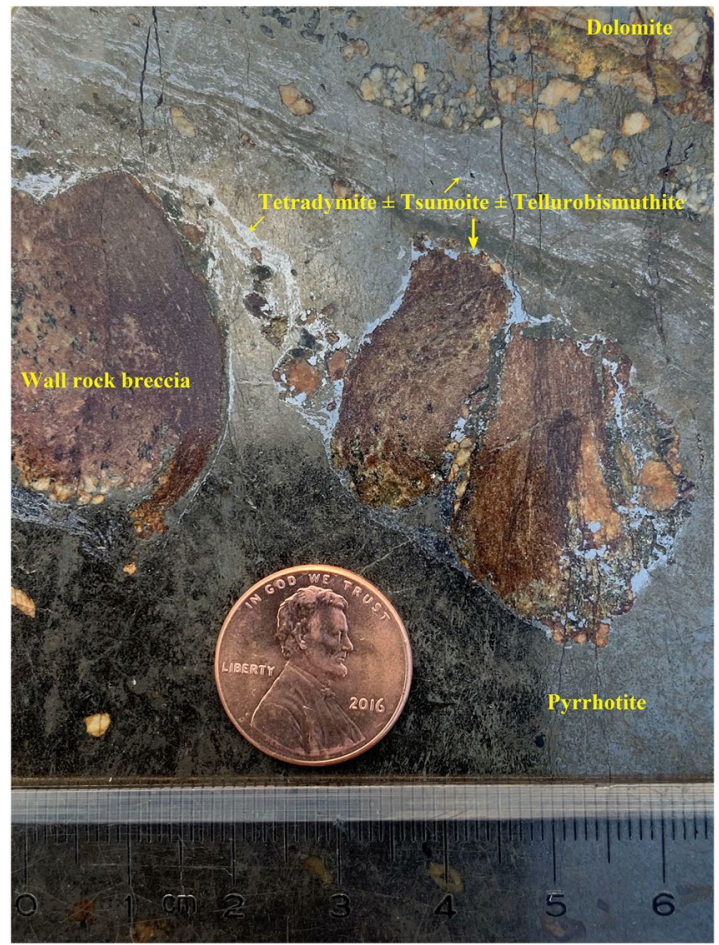

Figure 2. Lead grey-silvery colored tetradymite \pm tsumoite $(\mathrm{BiTe}) \pm$ tellurobismuthite $\left(\mathrm{Bi}_{2} \mathrm{Te}_{3}\right)$ fine veinlets in massive pyrrhotite (dark colored) + dolomite (brownish white) + wall rock (dark brown) from the deposit (sample \#: SD34, Ore body \#I-1 in Drift 3).

indicate that the upper mantle below the region uplifts obviously. As a result, the area has characteristics of high heat flow.

There is also a low-velocity, low resistivity zone in the middle crust that is interpreted as a decollement. The abnormal mantle exists under the crust in the region. It has properties of both geosyncline and platform, as well as special characteristics of its own. The belt is a geo-tectonically active zone with very complicated igneous 


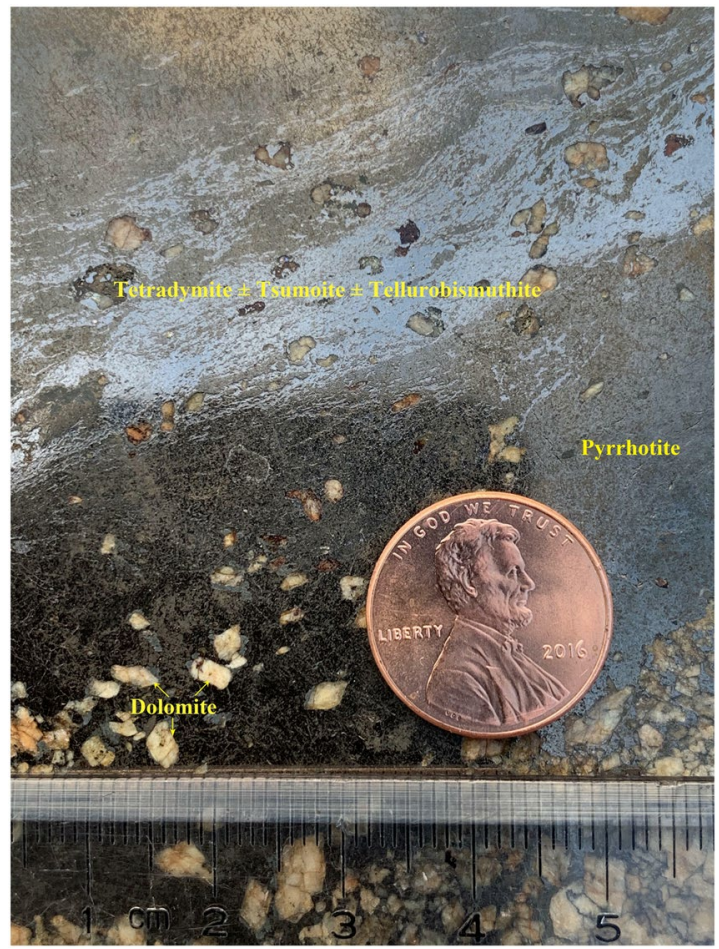

Figure 3. Lead grey-silvery colored tetradymite \pm tsumoite $(\mathrm{BiTe}) \pm$ tellurobismuthite $\left(\mathrm{Bi}_{2} \mathrm{Te}_{3}\right)$ fine veinlets in massive pyrrhotite (dark colored background) + dolomite (brownish white) from the deposit (sample \#: SD40, Ore body \#I-1 in Drift 3).

\begin{tabular}{|l|l|l|l|l|}
\hline wave length $(\mathbf{n m})$ & $\mathbf{4 7 0}$ & $\mathbf{5 4 6}$ & $\mathbf{5 8 9}$ & $\mathbf{6 5 0}$ \\
\hline sample \# & $\mathbf{R} \%$ & \multicolumn{4}{l|}{} \\
\hline 1 & 49.7 & 51.5 & 51.3 & 51.7 \\
\hline 2 & 54.5 & 55.1 & 55.8 & 56.6 \\
\hline 3 & 46.7 & 47.0 & 47.5 & 49.7 \\
\hline Standard sample & \multicolumn{5}{|l}{ black glass: $R \%$ (air) $\sim 4.5 \%$} \\
\hline
\end{tabular}

Table 1. Reflectance (R) of tetradymite from the Dashuigou tellurium deposit. Instrument: German Leitz MPV-3 microscopic photometer.

\begin{tabular}{|l|l|l|l|l|l|l|}
\hline \multirow{2}{*}{ sample \# } & \multicolumn{6}{|l|}{$\mathbf{k g} / \mathbf{m m}^{2}$} \\
\cline { 2 - 7 } & Hv25 & Hv50 & Hv25 & Hv50 & average & determination range \\
\hline 1 & 30.5 & & 37.0 & & 33.8 & $20.0 \sim 80.0$ \\
\hline 2 & 38.9 & 37.1 & & & 38.0 & the equivalent of \\
\hline 3 & & 66.3 & & 45.3 & 55.8 & $1 \sim 2$ on Mohs scale \\
\hline
\end{tabular}

Table 2. Micro-pressure harness (Hv) of tetradymite from the Dashuigou tellurium deposit. Instrument: German Leitz ORTHO PLAN micro-hardness tester.

rock structures. According to the regional geophysical data, the region's characteristics exhibit high velocity, high density, high resistance, high geothermal flow, high magnetism as well as well-developed earthquakes and mantle's uplift. In summary, this region is both geologically very active and a very important south-north trending tectonomagmatic-mineral belt ${ }^{3-5}$.

The strata, igneous rocks and structures trend south-northward. The strata are low-grade metamorphic rocks of the Silurian, Devonian, Permian systems and middle-lower Triassic series. A large amount of Archaean metamorphic rocks of the Kangding Group emerge to the southeast of the deposit. The well-developed igneous rocks in the region include ultrabasic, basic, neutral, acid and alkaline, produced in different geological times. Different types of mineral resources in the region are very rich; many of these are well known, including $\mathrm{Ti}, \mathrm{V}, \mathrm{Cu}, \mathrm{Pb}, \mathrm{Zn}$, SM, REE, coal, asbestos and the Panzhihua Vanadium Titano-magnetite deposit ${ }^{3-5}$. 


\begin{tabular}{|l|l|l|l|l|l|l|l|l|l|l|l|l|l|}
\hline sample \# & Vein & $\mathbf{T e}$ & $\mathbf{B i}$ & $\mathbf{S}$ & $\mathbf{F e}$ & $\mathbf{C u}$ & $\mathbf{A s}$ & $\mathbf{N i}$ & $\mathbf{Z n}$ & $\mathbf{A u}$ & $\mathbf{A g}$ & Total & chemical formula \\
\hline $\mathrm{SD} 34$ & \# I-4 & 34.75 & 60.29 & 4.57 & 0.03 & 0.04 & 0.09 & 0.01 & 0.09 & 0.01 & 0.02 & 99.90 & $\mathrm{Bi}_{2.00} \mathrm{Te}_{1.89} \mathrm{~S}_{0.99}$ \\
\hline $\mathrm{SD} 36$ & \# I-5 & 34.80 & 60.24 & 4.42 & 0.03 & 0.02 & 0.10 & 0.02 & 0.06 & 0.02 & 0.04 & 99.75 & $\mathrm{Bi}_{2.00} \mathrm{Te}_{1.89} \mathrm{~S}_{0.96}$ \\
\hline SD41 & \# I-1 & 34.54 & 60.22 & 4.81 & 0.13 & 0.04 & 0.00 & 0.02 & 0.06 & 0.03 & 0.04 & 99.89 & $\mathrm{Bi}_{2.00} \mathrm{Te}_{1.88} \mathrm{~S}_{1.04}$ \\
\hline SD45 & \# I-2 & 34.38 & 59.48 & 4.78 & 0.03 & 0.04 & 0.00 & 0.15 & 0.10 & 0.01 & 0.08 & 99.05 & $\mathrm{Bi}_{2.00} \mathrm{Te}_{1.89} \mathrm{~S}_{1.05}$ \\
\hline SD53 & \# I-10 & 34.58 & 60.03 & 4.71 & 0.14 & 0.05 & 0.05 & 0.09 & 0.10 & 0.03 & 0.02 & 99.80 & $\mathrm{Bi}_{2.00} \mathrm{Te}_{1.89} \mathrm{~S}_{1.02}$ \\
\hline SD59 & \# I-10 & 34.57 & 60.21 & 4.38 & 0.09 & 0.05 & 0.05 & 0.09 & 0.11 & 0.03 & 0.00 & 99.58 & $\mathrm{Bi}_{2.00} \mathrm{Te}_{1.88} \mathrm{~S}_{0.95}$ \\
\hline average & & 34.60 & 60.08 & 4.61 & 0.08 & 0.04 & 0.05 & 0.06 & 0.09 & 0.02 & 0.03 & 99.66 & $\mathrm{Bi}_{2.00} \mathrm{Te}_{1.89} \mathrm{~S}_{1.00}$ \\
\hline
\end{tabular}

Table 3. Electron-microprobe data of tetradymite from the Dashuigou tellurium deposit (\%).

\begin{tabular}{|l|l|l|l|}
\hline Mineral & $\begin{array}{l}\text { ICSD } \\
\text { Collection } \\
\text { Code }\end{array}$ & Ideal Formula & SD-40 \\
\hline Tetradymite & 26720 & $\mathrm{Bi}_{2} \mathrm{Te}_{2} \mathrm{~S}$ & 51.5 \\
\hline Tsumoite & 100654 & $\mathrm{BiTe}$ & 11.5 \\
\hline Tellurobismuthite & 74348 & $\mathrm{Bi}_{2} \mathrm{Te}_{3}$ & 1.9 \\
\hline Pyrrhotite 4C & 42491 & $\mathrm{Fe}_{7} \mathrm{~S}_{8}$ & 26.1 \\
\hline Ankerite- Dolomite & 66333 & $\begin{array}{l}\mathrm{Ca}\left(\mathrm{Fe}^{2+}, \mathrm{Mg}, \mathrm{Mn}\right)\left(\mathrm{CO}_{3}\right)_{2}- \\
\mathrm{CaMg}\left(\mathrm{CO}_{3}\right)_{2}\end{array}$ & 8.1 \\
\hline Chalcopyrite & 80095 & $\mathrm{CuFeS}_{2}$ & 0.5 \\
\hline Quartz & 174 & $\mathrm{SiO}_{2}$ & 0.4 \\
\hline Total & & & 100.0 \\
\hline
\end{tabular}

Table 4. Results of quantitative phase analysis (wt.\%) - project 1902410 - PO\# 18576.

\section{Geology of the Deposit}

The strata of the area are low-grade metamorphic rocks of the lower-middle Triassic age, including marble, slate and schist. The main wall-rocks of the ore bodies are schist and slate. All of the Triassic strata make up a NNE-trending dome. The geological and geochemical characteristics in the area indicate that the protolith of the tellurium ore veins' direct wall-rocks is poorly differentiated mantle-derived basalt ${ }^{3-7}$.

Both faults and folds are well-developed in the area. The annular and linear structures together make up special “ $\varnothing$ ” pattern structures, which control the formation of different types of endogenetic mineral deposits, including the Dashuigou tellurium deposit.

No intrusive rocks emerge within a $5 \mathrm{~km}$ radius around the deposit. Only two small Permian ultrabasic-basic rock bodies emerge within a $10 \mathrm{~km}$ range of the deposit. Large neutral, acid and alkaline intrusive bodies exist beyond $10 \mathrm{~km}$, which are unrelated to the deposit.

Quantitative chemical analyses of $\mathrm{Te}, \mathrm{Bi}, \mathrm{Se}, \mathrm{As}, \mathrm{Au}, \mathrm{Ag}, \mathrm{Cu}, \mathrm{Pb}$ and $\mathrm{Zn}$ were conducted on different rock samples including granites, metamorphic rocks, altered rocks, and carbonate veins of different geological times. The main findings are summarized below ${ }^{3-9}$.

The Te content in the granites is under $1 \times 10^{-7}$, which is similar to its Clark value in the Earth's crust. Te in the metamorphic rocks is slightly higher than in the granites and varies slightly between metamorphic rocks of different geological times, while being relatively higher in the Triassic metamorphic rocks. Of the metamorphic rocks in the same geological time, the Te content in the slate and schist is higher than in the marble. Te content in rocks of the same stratohorizon of the same geological time also varies; namely, it is higher in rocks within the mining area than in those beyond the mining area. Te content is closely related to the intensity of alterations; that is, the ore-forming elements are not derived from the country rocks, but instead from the mantle.

The deposit is located at the northeastern end of the Triassic metamorphic dome. The ore bodies are controlled by and fill a group of shear fractures. Nine tellurium ore veins have been discovered, which strike from 350 to 10 degrees and dip at 55 to 70 degrees westward. Widths of the ore bodies vary between 25 and $30 \mathrm{~cm}$. The narrow ore bodies are in the shape of lenticular veins and have sharp contact with the wall rocks.

The altered rocks occur in narrow bands ranging between several centimeters and one meter in thickness. Altered zones beside the massive ore veins are narrower, at only several centimeters wide. The dominant alterations include dolomitization, silicification, biotitization, muscovitizaion, tourmalinization, sericitizaion, greisenization, and chloritization.

Approximately thirty minerals are identified in the ore, which include tetradymite, pyrrhotite, pyrite, dolomite, quartz, chalcopyrite, tsumoite (BiTe), tellurobismuthite $\left(\mathrm{Bi}_{2} \mathrm{Te}_{3}\right)$, galena, magnetite, gold, silver, electrum, ilmenite, calcite, calaverite, siderite, mannesite, rutile, muscovite, biotite, sericite, hornblende, chlorite, plagioclase, K-feldspar, tourmaline, hematite, garnet, apatite, and epidote. The first five minerals are the most important and comprise $85 \%$ of the ore ${ }^{3-9}$, though tetradymite is so rare that many monographs on mineralogy do not have any related data on $\mathrm{it}^{10-12}$.

Replacement, remnant, reaction border, and granular are the dominating textures of the ore. Massive, vein/ veinlet, stockwork veins are the dominating structures of the deposit (Figs. 2 and 3). 


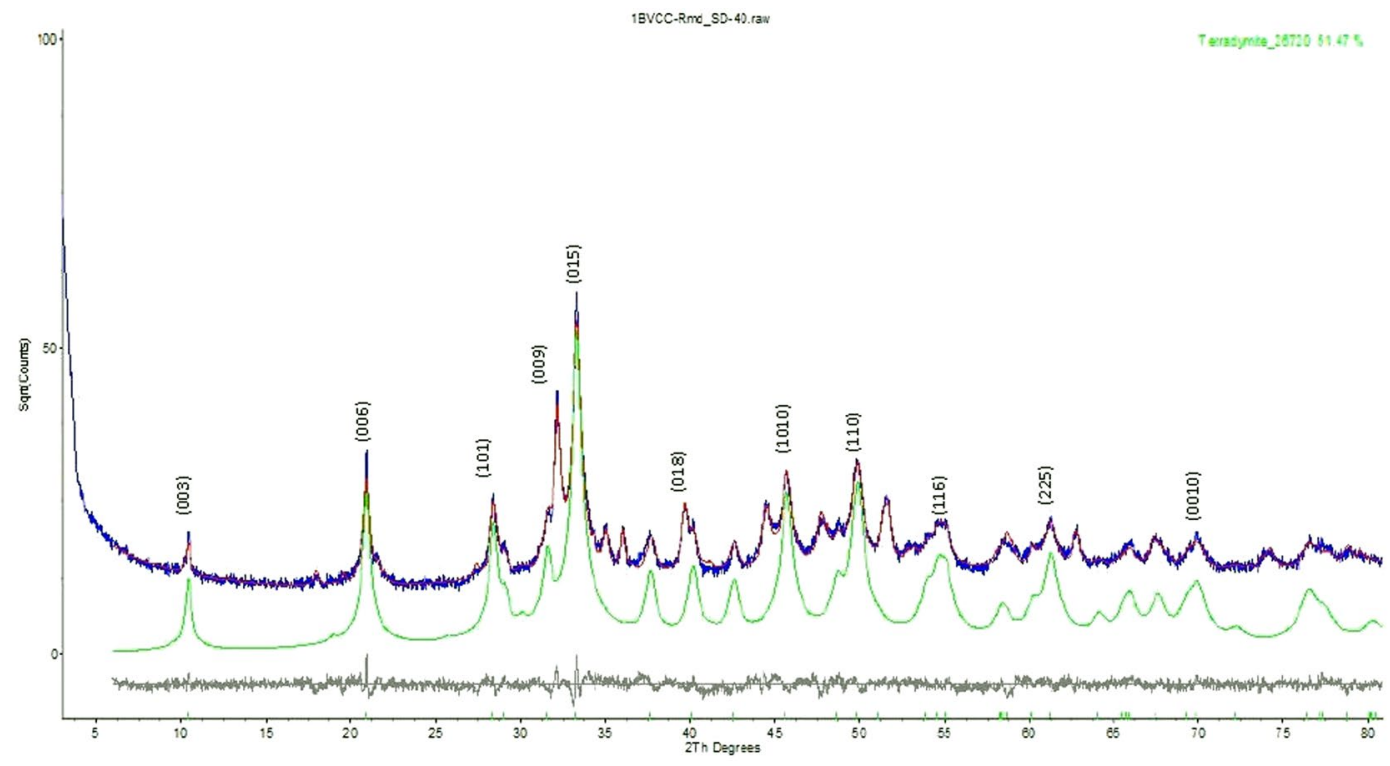

Figure 4. Rietveld refinement plot of sample SD-40 (blue line - observed intensity at each step; red line calculated pattern; solid grey line below - difference between observed and calculated intensities; vertical bars - positions of all Bragg reflections).

\begin{tabular}{|c|c|c|c|c|c|c|c|c|c|}
\hline \multirow[b]{2}{*}{ Phase Name } & \multirow{2}{*}{$\begin{array}{l}\text { ICSD } \\
\text { Collection } \\
\text { Code }\end{array}$} & \multirow[b]{2}{*}{ SG } & \multicolumn{7}{|c|}{ Refined Values } \\
\hline & & & wt.\% & $\mathbf{a}(\AA)$ & b $(\AA)$ & c $(\AA)$ & alpha $\left(^{\circ}\right)$ & $\operatorname{beta}\left({ }^{\circ}\right)$ & $\mathbf{V}\left(\AA^{3}\right)$ \\
\hline Tetradymite & 26720 & $\mathrm{R}-3 \mathrm{R}$ & 51.5 & 10.172 & & & 24.113 & & 154.391 \\
\hline Tsumoite & 100654 & P-3m1 & 11.5 & 4.432 & & 23.995 & & & 408.294 \\
\hline Tellurobismuthite & 74348 & $\mathrm{R}-3 \mathrm{mH}$ & 1.9 & 4.397 & & 30.512 & & & 510.975 \\
\hline Pyrrhotite & 42491 & $\mathrm{C} 12 / \mathrm{cl}$ & 26.1 & 11.935 & 6.864 & 12.834 & & 117.236 & 934.840 \\
\hline Dolomite & 66333 & $\mathrm{R}-3 \mathrm{H}$ & 8.1 & 4.679 & & 16.573 & & & \begin{tabular}{|l|}
314.297 \\
\end{tabular} \\
\hline Chalcopyrite & 80095 & I- $42 \mathrm{~d}$ & 0.5 & 5.295 & & 10.402 & & & 291.630 \\
\hline Quartz low & 174 & P3221S & 0.4 & 4.929 & & 5.361 & & & 112.811 \\
\hline Total & & & 100.0 & & & & & & \\
\hline
\end{tabular}

Table 5. Results of quantitative phase analysis (wt.\%) XRD-Rietveld and lattice parameters.

The most important ores are massive and the secondary ores are disseminated. The Te content in the ore varies between $0.01 \%$ and $34.58 \%$.

Two mineralization epochs and five stages exist in the deposit:

- Pyrrhotite epoch (177.7 165.1 Ma): including three mineralization stages: carbonate stage (I) $\rightarrow$ pyrrhotite stage (II) $\rightarrow$ chalcopyrite stage (III) (from early to late);

- Tellurium epoch (91.71 80.19Ma): including two mineralization stages, namely: tetradymite stage (I) $\rightarrow$ tsumoite $\left(\mathrm{BiTe}_{0.97}\right)$ stage $(\mathrm{II})^{3,4,13,14}$.

\section{Mineralogy of Tetradymite}

Mineragraphy. Tetradymite is the most common telluride and makes up more than $90 \%$ of all the tellurides of the deposit. It occurs as a silvery-white fine- to coarse-grained flake with one group of complete cleavages and lower Moh's hardness (1.4 2.1). Reflectance of the tetradymite under the four standard wavelengths is listed in Table 1 with a reflectance color of yellowish white. Table 2 lists its micro-pressure hardness.

In addition to tetradymite, tsumoite $(\mathrm{BiTe})$ and tellurobismuthite $\left(\mathrm{Bi}_{2} \mathrm{Te}_{3}\right)$ occur as lamellar and myrmekitic intergrowths within tetradymite. These fine-grained minerals are therefore hard to separate (Figs. 2 and 3 ).

Members of the tetradymite group present complex problems, many of which remain unsolved due to incomplete data ${ }^{15}$

The group of compounds in the four-compound system Bi-Te-Se-S represents a particular challenge, not least because the number of natural occurrences of the phases that have been comprehensively documented remains limited ${ }^{16}$. The difficulties are compounded by the rarity of the species, the varying quality and limited 


\begin{tabular}{|c|c|c|c|c|c|c|}
\hline \multirow[b]{4}{*}{ Item } & \multicolumn{2}{|c|}{ tetradymite } & \multicolumn{2}{|c|}{ tetradymite } & \multicolumn{2}{|c|}{ kawazulite } \\
\hline & \multicolumn{2}{|c|}{$\mathrm{Bi}_{2.00} \mathrm{Te}_{1.89} \mathrm{~S}_{1.00}$} & \multicolumn{2}{|l|}{ N/A } & \multicolumn{2}{|c|}{$\mathrm{Bi}_{2.07} \mathrm{Te}_{1.95} \mathrm{Se}_{0.97} \mathrm{~S}_{0.05}$} \\
\hline & \multicolumn{2}{|c|}{ the Dashuigou mine } & \multicolumn{2}{|c|}{ JCPDS 19-1330 } & \multicolumn{2}{|c|}{\begin{tabular}{|l|} 
JCPDS 29-248 \\
\end{tabular}} \\
\hline & \multicolumn{2}{|c|}{$\begin{array}{l}\text { Sichuan Province, } \\
\text { China }\end{array}$} & \multicolumn{2}{|c|}{ Paonia, Colorada, USA } & \multicolumn{2}{|c|}{ the Kawazu mine } \\
\hline \multirow[t]{25}{*}{ sample source } & \multicolumn{2}{|c|}{ Nat. Museum of China } & \multicolumn{2}{|c|}{ U.S.Nat. Museum R-395 } & \multicolumn{2}{|c|}{ Shizuoka, Japan } \\
\hline & $d(\AA)$ & $\mathrm{I} / \mathrm{I}_{0}$ & $d(\AA)$ & $I / I_{0}$ & $d(\AA)$ & $\mathrm{I} / \mathrm{I}_{0}$ \\
\hline & 9.973 & 15 & & & 9.900 & 10 \\
\hline & 4.940 & 90 & 4.860 & 30 & 4.920 & 40 \\
\hline & 3.651 & 16 & 3.610 & 30 & 3.640 & 30 \\
\hline & 3.295 & 19 & 3.260 & 30 & 3.300 & 10 \\
\hline & 3.123 & 100 & 3.100 & 100 & 3.120 & 100 \\
\hline & 2.776 & 12 & 2.756 & 30 & 2.780 & 10 \\
\hline & 2.609 & 12 & 2.592 & 30 & 2.610 & 20 \\
\hline & 2.464 & 31 & 2.453 & 30 & 2.460 & 10 \\
\hline & 2.305 & 43 & 2.292 & 100 & 2.310 & 50 \\
\hline & 2.169 & 14 & 2.159 & 50 & 2.170 & 10 \\
\hline & 2.123 & 27 & 2.111 & 75 & 2.120 & 50 \\
\hline & 1.971 & 27 & 1.965 & 75 & 1.977 & 10 \\
\hline & 1.938 & 21 & 1.929 & 75 & 1.933 & 10 \\
\hline & 1.832 & 5 & 1.825 & 30 & 1.832 & 10 \\
\hline & 1.783 & 6 & 1.776 & 30 & 1.757 & 20 \\
\hline & 1.755 & 14 & 1.743 & 50 & & \\
\hline & 1.683 & 4 & 1.679 & 10 & & \\
\hline & 1.644 & 32 & 1.638 & 756 & 1.648 & 10 \\
\hline & 1.607 & 8 & 1.603 & 50 & 1.609 & 6 \\
\hline & 1.569 & 13 & 1.569 & 50 & 1.571 & 10 \\
\hline & & & 1.556 & 50 & 1.560 & 10 \\
\hline & 1.517 & 4 & 1.513 & 10 & & \\
\hline & 1.445 & 10 & 1.441 & 50 & 1.447 & 10 \\
\hline X-ray & 1.428 & 6 & 1.426 & 30 & & \\
\hline diffraction & 1.408 & 4 & 1.407 & 10 & & \\
\hline data & 1.386 & 4 & 1.383 & 10 & & \\
\hline & 1.370 & 5 & 1.369 & 30 & & \\
\hline & 1.353 & 11 & 1.348 & 75 & 1.352 & 10 \\
\hline & 1.300 & 15 & 1.297 & 75 & 1.303 & 10 \\
\hline & 1.262 & 10 & 1.258 & 506 & & \\
\hline & 1.234 & 5 & 1.232 & 10 & & \\
\hline & & & 1.222 & 10 & & \\
\hline & 1.213 & 18 & 1.212 & 75 & & \\
\hline & 1.187 & 5 & 1.184 & 30 & & \\
\hline & 1.172 & 3 & 1.172 & 10 & & \\
\hline & 1.151 & 3 & & & & \\
\hline & 1.113 & 2 & 1.108 & 10 & & \\
\hline & 1.097 & 4 & 1.096 & 10 & & \\
\hline & 1.086 & 4 & 1.085 & 30 & & \\
\hline & 1.054 & 6 & 1.053 & 50 & & \\
\hline & 1.041 & 4 & & & & \\
\hline & 1.015 & 13 & 1.015 & 75 & & \\
\hline & & & 1.003 & 30 & & \\
\hline & 0.982 & 5 & 0.986 & 30 & & \\
\hline & & & 0.973 & 10 & & \\
\hline & 0.965 & 5 & 0.962 & 30 & & \\
\hline & 0.954 & 4 & & & & \\
\hline & 0.945 & 6 & 0.943 & 50 & & \\
\hline & 0.931 & 4 & & & & \\
\hline & 0.915 & 7 & 0.915 & 50 & & \\
\hline & 0.907 & 4 & 0.906 & 10 & & \\
\hline Continued & & & & & & \\
\hline
\end{tabular}




\begin{tabular}{|c|c|c|c|c|c|}
\hline \multirow[b]{4}{*}{ Item } & \multicolumn{2}{|c|}{ tetradymite } & \multicolumn{2}{|c|}{ tetradymite } & kawazulite \\
\hline & \multicolumn{2}{|c|}{$\mathrm{Bi}_{2.00} \mathrm{Te}_{1.89} \mathrm{~S}_{1.00}$} & \multicolumn{2}{|l|}{ N/A } & $\mathrm{Bi}_{2.07} \mathrm{Te}_{1.95} \mathrm{Se}_{0.97} \mathrm{~S}_{0.05}$ \\
\hline & \multicolumn{2}{|c|}{ the Dashuigou mine } & \multicolumn{2}{|c|}{ JCPDS 19-1330 } & JCPDS 29-248 \\
\hline & \multicolumn{2}{|c|}{$\begin{array}{l}\text { Sichuan Province, } \\
\text { China }\end{array}$} & \multicolumn{2}{|c|}{ Paonia, Colorada, USA } & the Kawazu mine \\
\hline \multirow[t]{5}{*}{ sample source } & \multicolumn{2}{|c|}{ Nat. Museum of China } & \multicolumn{2}{|c|}{ U.S.Nat. Museum R-395 } & Shizuoka, Japan \\
\hline & 0.896 & 8 & 0.896 & 50 & \\
\hline & & & \multicolumn{2}{|c|}{ plus 3 lines to 0.8258} & \\
\hline & \multicolumn{2}{|l|}{$\mathrm{CuKa}$} & \multicolumn{2}{|c|}{$\mathrm{CuKa}$} & $\mathrm{CuKa}$ \\
\hline & \multicolumn{2}{|c|}{ voltage: $40 \mathrm{kV}$} & \multicolumn{2}{|c|}{$\mathrm{l}=1.5418 \AA$} & $1=1.5418 \AA$ \\
\hline \multirow{4}{*}{ test conditions } & \multicolumn{2}{|c|}{ electricity: $50 \mathrm{~mA}$} & \multicolumn{2}{|c|}{ Ni filtration } & Ni filtration \\
\hline & \multicolumn{2}{|c|}{$\begin{array}{l}\text { slit: } \mathrm{DS}=\mathrm{SS}=1, \\
\mathrm{RS}=0.15\end{array}$} & \multicolumn{2}{|c|}{$\begin{array}{l}\text { camera diameter: } \\
14.3 \mathrm{~mm}\end{array}$} & $\begin{array}{l}\text { camera diameter: } \\
57.3 \mathrm{~mm}\end{array}$ \\
\hline & \multicolumn{2}{|c|}{$\begin{array}{l}\text { scanning speed: } 2 \mathrm{deg} / \\
\text { min }\end{array}$} & & & \\
\hline & \multicolumn{2}{|c|}{ step: $0.02 \mathrm{deg}$} & & & \\
\hline crystal system & \multicolumn{2}{|c|}{ hexagonal system } & \multicolumn{2}{|c|}{ hexagonal system } & hexagonal system \\
\hline unit cell & \multicolumn{2}{|c|}{$a=4.239$} & \multicolumn{2}{|c|}{$a=4.238$} & $a=4.240$ \\
\hline parameters & $c=29$ & & $c=29$ & & $c=29.660$ \\
\hline space group & $R 3 m$ & & $R 3 m$, & & $R 3 m, 32 / m$ \\
\hline
\end{tabular}

Table 6. Comparison of X-ray diffraction data of tetradymite from Dashuigou deposit and tetradymite/ kawazulite from deposits of other countries.

quantity of published data including reflectance and micro-pressure hardness of tetradymite, and by the invariably smaller-grained size and intergrown character of the mineral. Since the published data on reflectance and micro-pressure hardness of tetradymite is not plentiful, it does not permit a comparison and confirmation regarding the normality of these results.

Chemical compositions \& formula. Four of the nine tellurium veins in total had been mined out by the time this research started. As a result, all samples were collected from the five remaining veins. Chemical compositions of the tetradymite analyzed by electronic probe are listed in Table 3.

Based on the results presented in Table 3, chemical compositions of the tetradymite samples collected from different ore bodies of the mine are very similar: Te content varies between $34.38 \sim 34.80 \%$ with a maximum difference of $0.42 \%$ and average of $34.60 \%$; Bi content varies between $59.48 \sim 60.29 \%$ with a maximum difference of $0.81 \%$ and average of $60.08 \%$; $S$ content varies between $4.38 \sim 4.81 \%$ with a maximum difference of $0.43 \%$ and average of $4.61 \%$.

Synthetic tetradymite $\left(\mathrm{Bi}_{2} \mathrm{Te}_{1.9} \mathrm{~S}_{1.1}\right)$, which is similar to the tetradymite from the Dashuigou deposit, and two compounds, $\mathrm{Bi}_{48} \mathrm{Te}_{21} \mathrm{~S}_{31}$ and $\mathrm{Bi}_{5} \mathrm{Te}_{3} \mathrm{~S}_{2}$, were generated at $400^{\circ} \mathrm{C}$. Sulfur-rich tetradymite appears more chemically stable than stoichiometric $\mathrm{Bi}_{2} \mathrm{Te}_{2} \mathrm{~S}^{16}$.

The contents of trace elements in the tetradymite are similar to those in the mine's pyrrhotite and pyrite. The only difference is tetradymite is richer in gold than both the pyrite and pyrrhotite, which is identical to the observation results under microscope study of the minerals. This indicates that gold formed in the tellurium epoch mentioned above.

X-Ray power diffraction data. Due to insufficient quantity of the tetradymite mineral, single-crystal $\mathrm{X}$-ray studies are lacking and previous X-ray diffraction data and unit cell parameters of tetradymite were mainly obtained via crystal powder photography, the accuracy of which is not very satisfactory.

The quantitative phase analysis of one powder sample (\#SD-40, Fig. 3) using the RIETVELD method and X-ray powder diffraction data, Project 1902410 - PO\# 18576, was done by Jacob Kabel, and Dr. Elisabetta Pani, et al. from Dept. of Earth, Ocean \& Atmospheric Sciences, the University of British Columbia, Canada in December, 2019.

Experimental method and procedure. The sample SD-40 was reduced to the optimum grain-size range for quantitative X-ray analysis $(<10 \mu \mathrm{m})$ by grinding under ethanol in a vibratory McCrone Micronizing Mill for $10 \mathrm{~min}$ utes. Continuous-scan X-ray powder-diffraction data were collected over a range $3-80^{\circ} 2$ with CoK $\alpha$ radiation on a Bruker D8 Advance Bragg-Brentano diffractometer equipped with an Fe filter foil, $0.6 \mathrm{~mm}\left(0.3^{\circ}\right)$ divergence slit, incident- and diffracted-beam Soller slits and a LynxEye-XE detector. The long fine-focus Co X-ray tube was operated at $35 \mathrm{kV}$ and $40 \mathrm{~mA}$, using a take-off angle of $6^{\circ}$.

Results. The X-ray diffractogram was analyzed using the International Centre for Diffraction Database PDF-4 and Search-Match software by Bruker. X-ray powder-diffraction data of the sample were refined with Rietveld program Topas 4.2 (Bruker AXS). The results of quantitative phase analysis by Rietveld refinements are given in 


\begin{tabular}{|c|c|c|c|c|c|c|}
\hline \multirow[b]{2}{*}{ series \# } & \multirow[b]{2}{*}{ sample \# } & \multirow{2}{*}{\begin{tabular}{|l|} 
location \\
vein \# \\
\end{tabular}} & \multicolumn{3}{|c|}{ unit cell parameters } & \multirow[b]{2}{*}{ note } \\
\hline & & & $a(\AA)$ & $c(\AA)$ & $v\left(\AA^{3}\right)$ & \\
\hline 1 & SD34 & \# I-4 & 4.236 & 29.594 & 459.943 & \\
\hline 2 & SD36 & \# I-5 & 4.239 & 29.651 & 461.424 & \\
\hline 3 & SD40 & \# I-1 & 4.261 & 29.641 & 461.710 & \\
\hline 4 & SD46 & \# I-2 & 4.241 & 29.538 & 460.038 & instrument: \\
\hline 5 & SD58 & \# I-10 & 4.239 & 29.595 & 460.594 & Rigaku D/max-rC \\
\hline 6 & SD59 & \# I-10 & 4.248 & 29.582 & 462.366 & \\
\hline 7 & SD61 & \# I-10 & 4.238 & 29.569 & 459.830 & \\
\hline \multicolumn{2}{|l|}{ average } & & 4.240 & 29.596 & 460.843 & \\
\hline \multirow{2}{*}{ tetradymite } & USNM & Paonia & \multirow{2}{*}{4.238} & \multirow{2}{*}{29.589} & \multirow{2}{*}{$\mathrm{N} / \mathrm{A}$} & according to \\
\hline & R-395 & Cololado, USA & & & & JCPDS 19-1330 \\
\hline kawazulite & & $\begin{array}{l}\text { Kawazu mine, } \\
\text { Japan }\end{array}$ & 4.240 & 29.660 & N/A & JCPDS 29-248 \\
\hline
\end{tabular}

Table 7. Unit cell parameters of tetradymite from Dashuigou deposit and its comparisons with tetradymite/ kawazulite from other countries. test conditions of tetradymite from the Dashuigou mine: $\mathrm{CuKa}$ radiation, voltage: $40 \mathrm{kV}$, electricity: $50 \mathrm{~mA}$, slit: $\mathrm{DS}=\mathrm{SS}=1, \mathrm{RS}=0.15$, scanning speed: $2 \mathrm{deg} / \mathrm{min}$, step: $0.02 \mathrm{deg}$, smooth count: 11 .

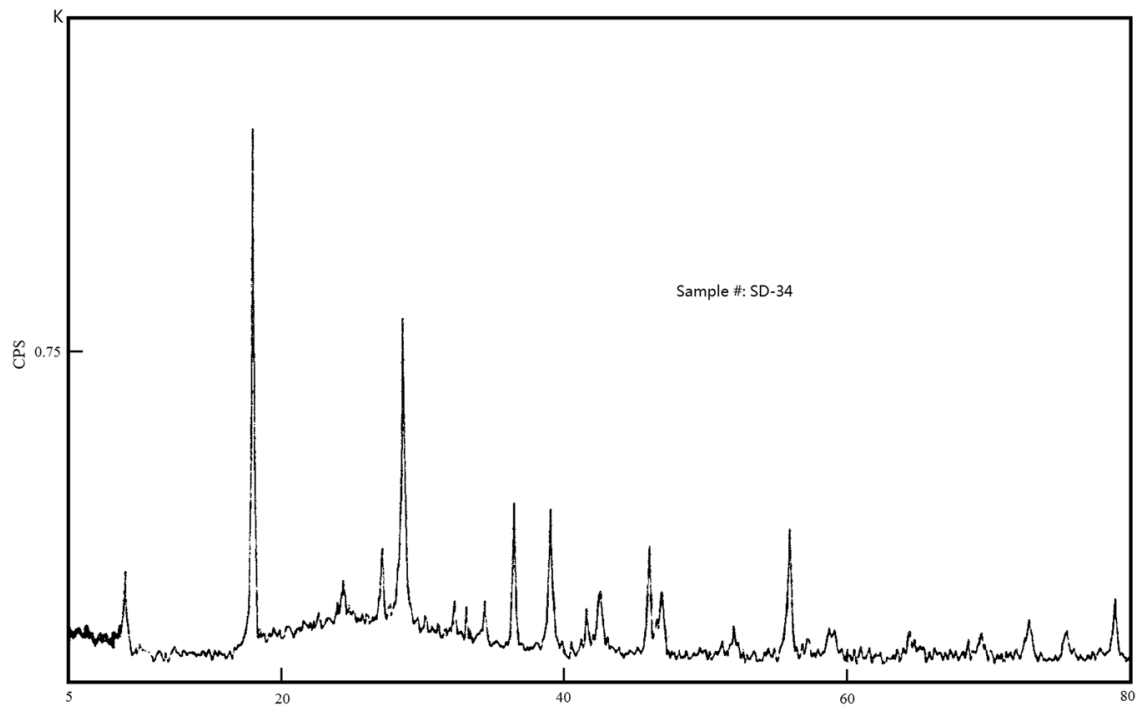

Figure 5. X-ray crystal power diffractogram of tetradymite from Dashuigou deposit.

Table 4. These amounts represent the relative amounts of crystalline phases normalized to $100 \%$. The Rietveld refinement plot is shown in Fig. 4. Lattice parameters and volumes are given in Table 5.

Another X-ray crystal powder diffraction analysis done in lab of the Research Center of Standard Materials, China Academy of Metrological Sciences, Beijing of China reveals that the tetradymite from the Dashuigou tellurium deposit is different than that from the Paonia mine in Colorado, US, but similar to kawazulite from the Kawazu mine in Japan. Even so, tetradymite from the Dashuigou deposit is lacking in Se compared to the Japanese kawazulite (Tables 6 and 7 and Fig. 5).

Kawazulite, $\mathrm{Bi}_{2} \mathrm{Te}_{2} \mathrm{Se}$, which was originally described by Kato (1970) as the Se analogue of tetradymite, is isostructural with tetradymite, which has been synthesized by Glaz (1967), Evdokimenko and Tsypin (1971), and Abrikosov and Beglaryan (1973). The compositional limits of tetradymite have been known to be $\mathrm{Bi}_{2} \mathrm{Te}_{2} \mathrm{~S}-\mathrm{Bi}_{2} \mathrm{Te}_{1.7} \mathrm{~S}_{1.3} \mathrm{As}$ determined by Kuznetsov and Kanishcheva (1970). Pauing (1975) explained why the substitution of Te by $\mathrm{S}$ increases the chemical stability. The calculated intensities of an X-ray powder-diffraction pattern of kawazulite with the ordered tetradymite structure type are similar to the visually estimated observed X-ray powder-diffraction intensities of kawazulite (PDF 29-248). The visually estimated observed intensity data is not sufficiently accurate to exclude partial ordering of Se and $\mathrm{Te}^{15}$. Extensive solid-solution between $\mathrm{S}$ - and Se-bearing end members can be documented in many series; for instance, tetradymite - kawazulite, and continuous solid-solution between tetradymite and kawazulite is well developed ${ }^{16}$.

The experimental and calculated two theta values with hkl indices are listed in Table 8. 


\begin{tabular}{|c|c|c|c|c|c|c|c|}
\hline \multirow{2}{*}{\multicolumn{6}{|c|}{ Tetradymite (ICDD 00-42-1447) }} & \multirow{3}{*}{$\lambda$} & \multirow{3}{*}{\begin{tabular}{|l|} 
Co tube \\
1.79 \\
$2 \theta\left[^{\circ}\right]$ \\
\end{tabular}} \\
\hline & & & & & & & \\
\hline No. & h & k & 1 & $\mathbf{d}[\AA]$ & I [\%] & & \\
\hline 1 & 0 & 0 & 3 & 9.87 & 2 & & 0.00 \\
\hline 2 & 0 & 0 & 6 & 4.929 & 10 & & 0.00 \\
\hline 3 & 1 & 0 & 1 & 3.644 & 20 & & 0.00 \\
\hline 4 & 0 & 1 & 2 & 3.566 & 2 & & 0.00 \\
\hline 5 & 0 & 0 & 9 & 3.288 & 10 & & 0.00 \\
\hline 6 & 0 & 1 & 5 & 3.121 & 100 & & 0.00 \\
\hline 7 & 1 & 0 & 7 & 2.77 & 5 & & \begin{tabular}{|l|}
0.00 \\
\end{tabular} \\
\hline 8 & 0 & 1 & 8 & 2.606 & 5 & & 0.00 \\
\hline 9 & 0 & 0 & 12 & 2.4655 & 1 & & 0.00 \\
\hline 10 & 1 & 0 & 10 & 2.3033 & 20 & & 0.00 \\
\hline 11 & 0 & 1 & 11 & 2.17 & 5 & & 0.00 \\
\hline 12 & 1 & 1 & 0 & 2.1199 & 40 & & \begin{tabular}{|l|}
0.00 \\
\end{tabular} \\
\hline 13 & 1 & 1 & 3 & 2.0723 & 1 & & 0.00 \\
\hline 14 & 0 & 0 & 15 & 1.9709 & 2 & & \begin{tabular}{|l|}
0.00 \\
\end{tabular} \\
\hline 15 & 1 & 1 & 6 & 1.9473 & 10 & & 0.00 \\
\hline 16 & 1 & 0 & 13 & 1.9335 & 10 & & 0.00 \\
\hline 17 & 0 & 1 & 14 & 1.832 & 3 & & 0.00 \\
\hline 18 & 2 & 0 & 2 & 1.8232 & 1 & & 0.00 \\
\hline 19 & 1 & 1 & 9 & 1.7813 & 3 & & 0.00 \\
\hline 20 & 2 & 0 & 5 & 1.7538 & 20 & & 0.00 \\
\hline 21 & 0 & 2 & 7 & 1.6839 & 2 & & 0.00 \\
\hline 22 & 1 & 0 & 16 & 1.6512 & 1 & & \begin{tabular}{|l|}
0.00 \\
\end{tabular} \\
\hline 23 & 0 & 0 & 18 & 1.6434 & 3 & & 0.00 \\
\hline 24 & 1 & 1 & 12 & 1.6068 & 5 & & 0.00 \\
\hline 25 & 0 & 1 & 17 & 1.5721 & 1 & & \begin{tabular}{|l|}
0.00 \\
\end{tabular} \\
\hline 26 & 0 & 2 & 10 & 1.5598 & 10 & & 0.00 \\
\hline 27 & 2 & 0 & 11 & 1.5161 & 2 & & 0.00 \\
\hline 28 & 1 & 1 & 15 & 1.4435 & 5 & & 0.00 \\
\hline 29 & 0 & 2 & 13 & 1.4286 & 3 & & 0.00 \\
\hline 30 & 2 & 0 & 14 & 1.3861 & 2 & & 0.00 \\
\hline 31 & 1 & 2 & 2 & 1.3823 & 1 & & \begin{tabular}{|l|}
0.00 \\
\end{tabular} \\
\hline 32 & 0 & 1 & 20 & 1.3716 & 1 & & 0.00 \\
\hline 33 & 2 & 1 & 4 & 1.3634 & 1 & & 0.00 \\
\hline 34 & 1 & 2 & 5 & 1.3508 & 20 & & 0.00 \\
\hline 35 & 2 & 1 & 7 & 1.3184 & 1 & & 0.00 \\
\hline 36 & 1 & 1 & 18 & 1.2982 & 10 & & 0.00 \\
\hline 37 & 1 & 0 & 22 & 1.2626 & 1 & & \begin{tabular}{|l|}
0.00 \\
\end{tabular} \\
\hline 38 & 2 & 1 & 10 & 1.2561 & 10 & & \begin{tabular}{|l|}
0.00 \\
\end{tabular} \\
\hline 39 & 0 & 0 & 24 & 1.2329 & 2 & & 0.00 \\
\hline 40 & 3 & 0 & 0 & 1.2237 & 10 & & \begin{tabular}{|l|}
0.00 \\
\end{tabular} \\
\hline 41 & 0 & 1 & 23 & 1.2133 & 5 & & 0.00 \\
\hline 42 & 3 & 0 & 6 & 1.1876 & 2 & & 0.00 \\
\hline 43 & 2 & 1 & 13 & 1.1844 & 5 & & 0.00 \\
\hline 44 & 1 & 1 & 21 & 1.1719 & 1 & & 0.00 \\
\hline 45 & 1 & 2 & 14 & 1.1587 & 1 & & \begin{tabular}{|l|}
0.00 \\
\end{tabular} \\
\hline 46 & 2 & 0 & 20 & 1.1513 & 1 & & 0.00 \\
\hline 47 & 3 & 0 & 9 & 1.1475 & 1 & & 0.00 \\
\hline 48 & 2 & 1 & 16 & 1.1095 & 1 & & \begin{tabular}{|l|}
0.00 \\
\end{tabular} \\
\hline 49 & 0 & 0 & 27 & 1.0954 & 1 & & 0.00 \\
\hline 50 & 1 & 2 & 17 & 1.0846 & 1 & & 0.00 \\
\hline
\end{tabular}

Table 8. The hkl vs two theta of the tetradymite from the Dashuigou tellurium deposit*. *Barry Whittington, Senior Mineralogist - Pacific Zone, Bureau Veritas Minerals Pty Ltd, helped with the hkl calculation. 


\begin{tabular}{|c|c|c|c|c|c|c|c|c|}
\hline \multirow[b]{2}{*}{ sample \# } & location & TVG* & SVp & SVn & SVnp & pyroelectricity & conduction & \multirow{2}{*}{$\begin{array}{l}\text { EHS/ } \\
\text { TS** }\end{array}$} \\
\hline & vein \# & $\mathrm{mV}$ & $\mathrm{mV}$ & $\mathrm{mV}$ & $\mathrm{mV}$ & $\mathrm{a}\left(\boldsymbol{\mu V} /{ }^{\circ} \mathrm{C}\right)$ & type & \\
\hline SD34 & \# I-4 & $(-34.1 \sim-23.0)$ & 0 & -292.6 & -29.26 & -209.0 & $\mathrm{~N}$ & $0 / 10$ \\
\hline SD36 & \# I-5 & $(-42.0 \sim-30.7)$ & 0 & -364.0 & -36.40 & -260.0 & $\mathrm{~N}$ & $0 / 10$ \\
\hline SD40 & \# I-1 & $(-40.9 \sim-33.2)$ & 0 & -383.6 & -38.36 & -274.0 & $\mathrm{~N}$ & $0 / 10$ \\
\hline SD46 & $\# \mathrm{I}-2$ & $(-38.8 \sim-34.2)$ & 0 & -368.4 & -36.84 & -263.14 & $\mathrm{~N}$ & $0 / 10$ \\
\hline SD58 & \# I-10 & $(-37.0 \sim-29.5)$ & 0 & -334.6 & -33.46 & -239.0 & $\mathrm{~N}$ & $0 / 10$ \\
\hline SD59 & \# I-10 & $(-32.8 \sim-27.1)$ & 0 & -293.6 & -29.36 & -209.71 & $\mathrm{~N}$ & $0 / 10$ \\
\hline SD61 & \# I-10 & $(-41.2 \sim-33.5)$ & 0 & -345.8 & -34.58 & -247.0 & $\mathrm{~N}$ & $0 / 10$ \\
\hline average & & $(-38.11 \sim-29.89)$ & 0 & -304.4 & -30.04 & -243.12 & $\mathrm{~N}$ & $0 / 10$ \\
\hline excitation temperature & \multicolumn{8}{|l|}{$140^{\circ} \mathrm{C}$} \\
\hline
\end{tabular}

Table 9. Pyroelectricity of tetradymite from the Dashuigou tellurium deposit. Note: TVG* $=$ thermoelectric voltage range, EHS/TS** = electron hole sample/total sample.

Pyroelectricity. It is believed that pyroelectricity of minerals can be used to determine their origin and process of formation. Unfortunately, there existed no pyroelectricity data of tetradymite prior to the research of this paper.

Pyroelectricity of minerals can be divided into $\mathrm{N}$ (electron) type, $\mathrm{P}$ (electron hole) type and the mixed $\mathrm{N}$ and P type.

Pyroelectricity characteristics of the tetradymite from Dashuigou deposit are listed in Table 9.

The tetradymite from Dashuigou deposit is completely of $\mathrm{N}$ conduction type. All of its pyroelectricity is negative, and the values are both close to each other and vary between $-209.0 \sim-274.0 \mu \mathrm{V} /{ }^{\circ} \mathrm{C}$. With a maximum difference of $-65.0 \mu \mathrm{V} /{ }^{\circ} \mathrm{C}$ and an average of $-243.12 \mu \mathrm{V} /{ }^{\circ} \mathrm{C}$, the data implies that the tellurium veins were all formed in the same geological event and from the same source.

The negative pyroelectricity of the tetradymite resulted from insufficient sulfur, As and Se impurities, and other isomorphous mixtures of Te in tetradymite.

\section{Sulfur and Lead Isotopes of Tetradymite}

Sulfur isotope. Sulfur isotope results of the dominant sulfides collected from various veins of the deposit are provided in Table 10. It can be seen that sulfur isotopes of various sulfides formed in different veins of different metallogenic epochs and/or stages are very close to each other, varying within a narrow range with an average below $1 \%$, a crest value around $0.6 \%$, and a clear tower effect (Fig. 6).

Cao and Luo researched and published their $\delta^{34} \mathrm{~S}_{\mathrm{CDT}} \%$ o results of $1.13 \sim 3.17$ with an average of $1.966^{17}$, which indicated that sulfur isotopes of the Dashuigou deposit were very homogeneous and thus originated from the deep mantle.

In general, sulfur isotopes of the deposit are very similar to those of meteorite, moon rock and mantle-derived materials, indicating that the sulfurs are from the mantle. This finding is in agreement with Cao and Luo's studies ${ }^{17}$. The $\delta^{34} S_{\mathrm{CDT}} \%$ of series \#16 \& \#22 samples in Table 10, which are collected from regional country rocks far from the deposit, clearly deviate from that of samples collected from the deposit.

The series \#16 sample is coarse- to very coarse-grained cubic pyrite in the upper Permian metamorphosed basalt to the south of the deposit, while the series \#22 sample is chalcocite from the Shaoyaocao copper showing, demonstrating a connection to the basic to ultra-basic intrusive to the east of the deposit. In theory, $\delta^{34} \mathrm{~S}_{\mathrm{CDT}} \%$ o of these two samples should be close to that of mantle-derived materials $(-3 \sim 2)$, since their wall rocks are from the mantle. In fact, they are not similar to each other, which may be owed to the post metamorphism after their formation.

$\delta^{34} \mathrm{~S}_{\mathrm{CDT}} \%$ of all the pyrrhotite samples varies between $-3.1 \sim 2.1$ with an 8 -sample average of 0.175 , close to that of the meteorite, indicating that they are mantle derived. Meanwhile, $\delta^{34} \mathrm{~S}_{\mathrm{CDT}} \%$ of all the pyrite samples is between $1.4 \sim 2.8$ with a 6 -sample average of 1.717 , also close to that of meteorite and implying that they too are mantle derived.

$\delta^{34} \mathrm{~S}_{\mathrm{CDT}} \%$ of both the deposit's pyrrhotite and pyrite formed in the same metallogenic epoch are in a similar narrow scope. For samples \#SD-29 and SD-55 in Table 10, $\delta^{34}$ Spyrite $\%$ o $<\delta^{34}$ Spyrrhotite\%o, suggesting that the sulfur exchange between pyrite and pyrrhotite of these samples did not reach balance. For samples \#SD-23 and SD-41 in Table 10, $\delta^{34}$ Spyrite $\% 0>\delta^{34}$ Spyrrhotite $\%$, indicating that sulfur exchange between pyrite and pyrrhotite of these samples reached balance.

As shown in Table 10 and briefly discussed above, $\delta^{34} \mathrm{~S}_{\mathrm{CDT}} \%$ of both pyrrhotite and pyrite varies within a very narrow range, indicating that sulfur exchange between pyrite and pyrrhotite became highly uniform and achieved balance. As a result, $\delta^{34} S_{\Sigma s} \%$, the general sulfur component of the deposit's metallogenic hydrothermal solution, can be calculated by the following equation ${ }^{18}$ :

$$
\delta^{34} \mathrm{~S}_{\Sigma \mathrm{s}}=\Sigma \delta^{34} \mathrm{~S}_{i}=\mathrm{X}_{1} \delta^{34} \mathrm{~S}_{1}+\mathrm{X}_{2} \delta^{34} \mathrm{~S}_{2}+\cdots \cdots
$$

For the pyrrhotite (Pyr) and pyrite (Py) veins of the deposit's early metallogenic epoch, the specific equation should be as follows: 


\begin{tabular}{|c|c|c|c|c|c|}
\hline series \# & sample id & sample name & location & $\delta^{34} S_{\mathrm{CDT}}(\%)$ & note \\
\hline 1 & SD-10 & pyrrhotite & from a Pyr vein between \#II \& III Pyr Veins & -3.1 & \\
\hline 2 & SD-15 & & from \#III-1 Pyr Vein & -1.4 & \\
\hline 3 & SD-23 & & from \#I-4 Tellurium Vein & 1.2 & \\
\hline 4 & SD-29 & & from \#I-5 Tellurium Vein & 2.1 & \\
\hline 5 & SD-41 & & from \#I-1 Tellurium Vein & -0.1 & \\
\hline 6 & SD-55 & & from \#I-10 Tellurium Vein & 1.6 & \\
\hline 7 & SD-65 & & from \#I-8 Tellurium Vein & 0.6 & \\
\hline 8 & SD-71 & & from a Pyr vein of \#IV Ore Zone & 0.5 & \\
\hline 9 & SD-17 & pyrite & from \#III-2 Pyr Vein & 1.4 & scope* $^{*}$ \\
\hline 10 & SD-23 & & from \#I-4 Tellurium Vein & 1.7 & $(-3.1 \% 0 \sim$ \\
\hline 11 & SD-29 & & from \#I-5 Tellurium Vein & 2.0 & $2.8 \% 0)$ \\
\hline 12 & SD-41 & & from \#I-1 Tellurium Vein & 1.6 & \\
\hline 13 & SD-52 & & from a DV at marble-schist contact of the deposit & 2.8 & \\
\hline 14 & SD-55 & & from \#I-10 Tellurium Vein & 1.4 & \\
\hline 15 & SL-06 & & from a QV next to the deposit & -0.6 & range* \\
\hline 16 & SL-10 & & from the metamorphosed basalt next to the deposit & -5.7 & $5.9 \%$ \\
\hline 17 & SD-34 & tetradymite & from \#I-4 Tellurium Vein & -0.2 & \\
\hline 18 & SD-40 & & from \#I-1 Tellurium Vein & 0.6 & \\
\hline 19 & SD-46 & & from \#I-2 Tellurium Vein & 0.5 & \\
\hline 20 & SD-59 & & from \#I-10 Tellurium Vein & 1.4 & average*: \\
\hline 21 & SD-36 & & from \#I-5 Tellurium Vein & 0.3 & $0.72 \%$ \\
\hline 22 & SL-23 & chalcocite & from a copper showing next to the deposit & 8.2 & \\
\hline 23 & SD-10 & chalcopyrite & from a Pyr vein between \#II \& III Pyr Veins & -1.4 & \\
\hline 24 & SD-15 & & from \#III-1 Pyr Vein & 1.9 & \\
\hline 25 & SD-71 & & from a Pyr vein of \#IV Ore Zone & 0.5 & \\
\hline 26 & TB1 & tetradymite & free pickup from the ore stockpile & 0.4 & \\
\hline 27 & TB2 & & free pickup from the ore stockpile & 0.4 & \\
\hline 28 & TB3 & & free pickup from the ore stockpile & 2.1 & \\
\hline 29 & TB4 & & free pickup from the ore stockpile & 0.2 & \\
\hline 30 & TB5 & & free pickup from the ore stockpile & -0.5 & \\
\hline 31 & TB6 & & free pickup from the ore stockpile & 0.3 & \\
\hline 32 & TB7 & & free pickup from the ore stockpile & 0.8 & \\
\hline 33 & TB8 & & free pickup from the ore stockpile & 0.5 & \\
\hline 34 & TB9 & & free pickup from the ore stockpile & 0.5 & \\
\hline 35 & TB10 & & free pickup from the ore stockpile & 1.1 & \\
\hline
\end{tabular}

Table 10. Sulfur isotope results of the sulfides from the Dashuigou tellurium deposit. Note: Pyr-pyrrhotite, DVdolomite vein, QV-quartz vein, *only counting those samples collected within the deposit.

$$
\delta^{34} \mathrm{~S}_{\Sigma \mathrm{s}}=\mathrm{X}_{1} \delta^{34} \mathrm{~S}_{\mathrm{Pyr}}+\mathrm{X}_{2} \delta^{34} \mathrm{~S}_{\mathrm{Py}}
$$

Taking $\mathrm{X}_{1}=98 \%$ (Pyr\% by volume of total sulfides in the veins) and $\mathrm{X}_{2}=2 \%$ (Py\% by volume of total sulfides in the veins), average values of $\delta^{34} S_{\mathrm{Pyr}} \%$ and $\delta^{34} S_{\mathrm{Py}} \%$ are respectively 0.175 and 1.817 ; therefore, $\delta^{34} S_{\Sigma \mathrm{s}} \%$, the general sulfur component of the early metallogenic epoch's metallogenic hydrothermal solution should be:

$$
\delta^{34} S_{\Sigma s}=0.98 \times 0.175 \% 0+0.02 \times 1.817 \% 0=0.208 \% 0
$$

The general sulfur component of the early metallogenic epoch's hydrothermal solution is close to that of the meteorite and also indicates that the deposit's sulfur is derived from the mantle.

Sulfur isotopes of tetradymite $(\mathrm{Tt})$ formed in the late tellurium epoch of the deposit vary narrowly between $-0.5 \sim 2.1 \%$, with a range value of $2.6 \%$, a peak value around $0.5 \%$, and a 15 -sample average of $0.56 \%$, also close to that of the meteorite and mantle materials. Sulfur isotopes of chalcopyrite $(\mathrm{Cp})$ of the late tellurium epoch vary between $-1.4 \%$ and $1.9 \%$ with a range of $2.3 \%$ and a 3 -sample average of $0.33 \%$, likewise close to that of the meteorite and mantle materials.

Similarly as above, the general sulfur component $\delta^{34} S_{\Sigma s} \%$ of the late tellurium epoch's metallogenic hydrothermal solution can be calculated as follows:

$$
\delta^{34} \mathrm{~S}_{\Sigma \mathrm{s}}=\mathrm{X}_{1} \delta^{34} \mathrm{STt}+\mathrm{X}_{2} \delta^{34} \mathrm{~S}_{\mathrm{Cp}}=0.99 \times 0.56 \% 0+0.01 \times 0.33 \% 0=0.56 \% 0
$$




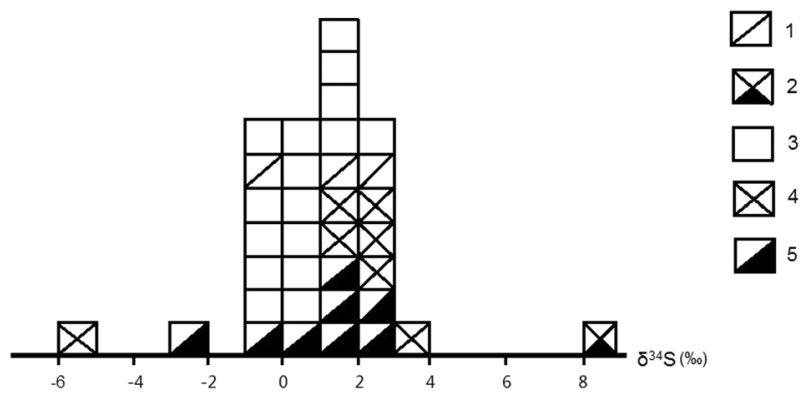

Figure 6. Histogram of $8^{34} \mathrm{~S}_{\mathrm{CDT}}(\%)$ of the dominant sulfides from the Dashuigou deposit. (35 samples in total included in Table 10). 1. chalcopyrite, 2. chalcocite, 3 . tetradymite, 4 . pyrite, 5 . Pyrrhotite.

\begin{tabular}{|c|c|c|c|c|c|c|c|c|c|c|c|c|}
\hline \multirow{2}{*}{$\begin{array}{l}\text { series } \\
\#\end{array}$} & \multirow{2}{*}{$\begin{array}{l}\text { sample } \\
\text { id }\end{array}$} & \multirow[b]{2}{*}{ name } & \multirow[b]{2}{*}{ location } & ${ }^{204} \mathrm{~Pb}$ & ${ }^{206} \mathrm{~Pb}$ & ${ }^{207} \mathrm{~Pb}$ & ${ }^{208} \mathrm{~Pb}$ & \multirow{2}{*}{$\frac{{ }^{206} \mathrm{~Pb}}{{ }^{204} \mathrm{~Pb}}$} & \multirow{2}{*}{$\frac{{ }^{207}}{{ }^{204} \mathrm{~Pb}}$} & \multirow{2}{*}{$\frac{{ }^{208}}{{ }^{204} \mathrm{~Pb}}$} & \multirow{2}{*}{\begin{tabular}{|l|}
$\mathrm{Pb}$ \\
Isotope \\
a. w.
\end{tabular}} & \multirow{2}{*}{$\begin{array}{l}\text { M.L.A } \\
\text { Ma }\end{array}$} \\
\hline & & & & \multicolumn{4}{|l|}{$\%$} & & & & & \\
\hline 1 & SD-10 & Pyr & between \#II \& III PV & 1.357 & 24.924 & 21.418 & 52.301 & 18.362 & 15.779 & 38.531 & 207.233 & 310.00 \\
\hline 2 & SD-15 & & from \#III-1 PV & 1.388 & 25.791 & 21.184 & 51.636 & 18.580 & 15.261 & 37.198 & 207.217 & 0.00 \\
\hline 3 & SD-23 & & next to \#I-4 Ore Vein & 1.401 & 24.980 & 21.446 & 52.173 & 17.833 & 15.309 & 37.245 & 207.230 & 235.00 \\
\hline 4 & SD-26 & & next to \#I-4 Ore Vein & 1.368 & 25.251 & 21.296 & 52.082 & 18.464 & 15.573 & 38.086 & 207.227 & 97.50 \\
\hline 5 & SD-29 & & next to \#I-5 Ore Vein & 1.370 & 25.066 & 21.304 & 52.260 & 18.291 & 15.546 & 38.136 & 207.231 & 185.00 \\
\hline 6 & SD-34 & & next to \#I-4 Ore Vein & 1.384 & 25.262 & 21.185 & 52.170 & 18.251 & 15.305 & 37.691 & 207.228 & 0.00 \\
\hline 7 & SD-41 & & next to \#I-1 Ore Vein & 1.355 & 26.382 & 21.014 & 51.249 & 19.473 & 15.511 & 37.828 & 207.208 & 0.00 \\
\hline 8 & SD-55 & & next to \#I-10 Ore Vein & 1.359 & 25.624 & 21.092 & 51.925 & 18.860 & 15.525 & 38.219 & 207.222 & 0.00 \\
\hline 9 & SD-65 & & next to \#I-8 Ore Vein & 1.353 & 24.753 & 21.972 & 51.922 & 18.294 & 16.238 & 38.373 & 207.231 & 916.25 \\
\hline 10 & SD-71 & & from a PV of \#IV OZ & 1.383 & 24.795 & 21.420 & 52.403 & 17.929 & 15.488 & 37.892 & 207.235 & 360.00 \\
\hline 11 & SD-17 & Py & from \#III-2 PV & 1.375 & 24.872 & 21.399 & 52.355 & 18.095 & 15.568 & 38.088 & 207.234 & 341.25 \\
\hline 12 & SD-23 & & next to \#I-4 Ore Vein & 1.411 & 24.921 & 21.463 & 52.206 & 17.665 & 15.214 & 37.006 & 207.231 & 235.00 \\
\hline 13 & SD-29 & & next to \#I-5 Ore Vein & 1.385 & 25.170 & 21.297 & 52.148 & 18.176 & 15.379 & 37.657 & 207.228 & 41.25 \\
\hline 14 & SD-41 & & next to \#I-1 Ore Vein & 1.375 & 24.871 & 21.407 & 52.348 & 18.090 & 15.570 & 38.075 & 207.234 & 360.00 \\
\hline 15 & SD-52 & & $\begin{array}{l}\text { from a dolomite vein at } \\
\text { marble and ore-bearing } \\
\text { schist contact }\end{array}$ & 1.378 & 25.271 & 21.260 & 52.091 & 18.338 & 15.428 & 37.799 & 207.227 & 0.00 \\
\hline 16 & SD-55 & & next to \#I-10 Ore Vein & 1.395 & 24.764 & 21.528 & 52.314 & 17.758 & 15.437 & 37.513 & 207.234 & 441.25 \\
\hline 17 & SL-10 & & $\begin{array}{l}\text { from meta-basalt }\left(\mathrm{P}_{2}^{1}\right) \\
\text { at the Liushapo next to } \\
\text { the deposit }\end{array}$ & 1.360 & 25.002 & 21.184 & 52.455 & 18.386 & 15.578 & 38.575 & 207.234 & 160.00 \\
\hline 18 & SD-34 & $\mathrm{Td}$ & from \#I-4 Ore Vein & 1.313 & 24.979 & 21.190 & 52.518 & 19.027 & 16.142 & 40.006 & 207.236 & 360.00 \\
\hline 19 & SD-36 & & from \#I-5 Ore Vein & 1.383 & 25.348 & 21.132 & 52.138 & 18.330 & 15.281 & 37.703 & 207.226 & 0.00 \\
\hline 20 & SD-40 & & from \#I-1 Ore Vein & 1.350 & 25.205 & 21.147 & 52.299 & 18.675 & 15.668 & 38.749 & 207.230 & 35.00 \\
\hline 21 & SD-46 & & from \#I-2 Ore Vein & 2.008 & 24.830 & 21.877 & 51.285 & 12.366 & 10.895 & 25.541 & 207.204 & 0.00 \\
\hline 22 & SD-59 & & from \#I-10 Ore Vein & 1.338 & 25.222 & 21.079 & 52.361 & 18.853 & 15.756 & 39.139 & 207.231 & 47.50 \\
\hline 23 & SL-01 & $\mathrm{G}\left(\gamma_{5}^{1}\right)$ & $\begin{array}{l}\text { from Niubeishan near } \\
\text { the mine }\end{array}$ & 1.319 & 26.305 & 20.712 & 51.664 & 19.947 & 15.706 & 39.177 & 207.214 & 0.00 \\
\hline 24 & SD-60 & $\mathrm{S}\left(\mathrm{T}_{1-2}\right)$ & $\begin{array}{l}\text { from the footwall of } \\
\# I-10 \text { ore vein }\end{array}$ & 1.371 & 25.248 & 21.103 & 52.279 & 18.419 & 15.395 & 38.139 & 207.229 & 0.00 \\
\hline
\end{tabular}

Table 11. Lead isotope results of samples from the study area. Note: a.w. - atomic weight; M.L.A - model lead age, the following primal lead isotope ratios are used to calculate the model lead. ages: $\mathrm{a}_{0}=9.307, \mathrm{~b}_{0}=10.294$, $\mathrm{c}_{0}=29.476, \mathrm{t}_{0}=4,430 \mathrm{Ma}$, decay constants $\lambda_{1}=1.55 \times 10^{-10} / \mathrm{a}, \lambda_{2}=9.85 \times 10^{-10} / \mathrm{a}$, and $\lambda_{3}=4.59 \times 10^{-11} / \mathrm{a}$. Pyr - pyrrhotite, Py - pyrite, Td - tetradymite, G - granite, S - slate, PV - pyrrhotite vein, OZ - ore zone. Lab: Institute of Geology \& Geophysics, Chinese Academy of Sciences.

The general sulfur component of the late tellurium metallogenic epoch's hydrothermal solution is close to that of the meteorite and demonstrates that the deposit's sulfur is derived from the mantle.

Per discussions on sulfur isotopes of the deposit's minerals above, the authors' preliminary conclusions are that $\delta^{34} S$ of both single sulfide minerals from different veins of different metallogenic epochs and the general total sulfur isotope components of the deposit's metallogenic hydrothermal solutions vary within very narrow scopes with very small ranges close to $0.0 \%$. As a result, the deposit's sulfur is very close to that of the meteorite and may be derived from the mantle. 


\begin{tabular}{|l|l|l|l|l|l|l|l|l|l|}
\hline \multicolumn{2}{|l|}{ series \# } & $\mathbf{1}$ & $\mathbf{2}$ & $\mathbf{3}$ & $\mathbf{4}$ & $\mathbf{5}$ & $\mathbf{6} *$ & $\mathbf{7}$ & $\mathbf{8}$ \\
\hline sample & & $\mathbf{P y r}$ & $\mathbf{P y}$ & $\mathbf{T d}$ & $\mathbf{G}$ & $\mathbf{P y}$ & $\mathbf{S}+\mathbf{S}$ & $\mathbf{M}$ & $\mathbf{B t}$ \\
\hline note & & \multicolumn{1}{l}{ collected from the deposit } & $\mathbf{Y}_{\mathbf{5}}{ }^{1}$ & $\mathbf{P}_{2}{ }^{1}$ & $\mathbf{T}_{1-2}$ & $\mathbf{T}_{1-2}$ & $\mathbf{P}_{2}$ \\
\hline \# of sample & & $\mathbf{1 0}$ & $\mathbf{6}$ & $\mathbf{5}$ & $\mathbf{1}$ & $\mathbf{1}$ & $\mathbf{3}$ & $\mathbf{1}$ & $\mathbf{2}$ \\
\hline & scope & $17.833 \sim$ & $17.665 \sim$ & $12.366 \sim$ & n/a & n/a & $18.419 \sim$ & n/a & $18.175 \sim$ \\
\hline & & 19.473 & 18.338 & 19.028 & & & 19.616 & & 18.235 \\
\hline & range & 1.640 & 0.673 & 6.661 & n/a & n/a & 1.197 & n/a & 0.030 \\
\hline & average & 18.434 & 18.020 & 17.450 & 19.947 & 18.386 & 18.833 & 19.803 & 18.205 \\
\hline & scope & $15.261 \sim$ & $15.214 \sim$ & $10.895 \sim$ & n/a & n/a & $15.367 \sim$ & n/a & $15.549 \sim$ \\
\hline & & 16.238 & 15.570 & 16.142 & & & 15.786 & & 15.629 \\
\hline & range & 0.978 & 0.356 & 5.247 & n/a & n/a & 0.419 & n/a & 0.040 \\
\hline & average & 15.554 & 15.433 & 14.748 & 15.706 & 15.578 & 15.516 & 15.818 & 15.589 \\
\hline & scope & $37.198 \sim$ & $37.006 \sim$ & $25.541 \sim$ & n/a & n/a & $38.139 \sim$ & n/a & $38.380 \sim$ \\
\hline & & 38.531 & 38.088 & 40.006 & & & 43.506 & & 38.490 \\
\hline & range & 1.333 & 1.082 & 14.465 & n/a & n/a & 5.367 & n/a & 0.053 \\
\hline & average & 37.920 & 37.690 & 36.228 & 39.177 & 38.575 & 40.202 & 38.932 & 38.425 \\
\hline
\end{tabular}

Table 12. Summarized characteristics of lead isotopes of samples from the study area. Note: Pyr - pyrrhotite, Py - pyrite, Td - tetradymite, G - granite, $S+S$ - slate \& schist, $M$ - marble, Bt - basalt, * - results of 2 of the 3 sample of series \#6 sample are after Wang ${ }^{19}$.

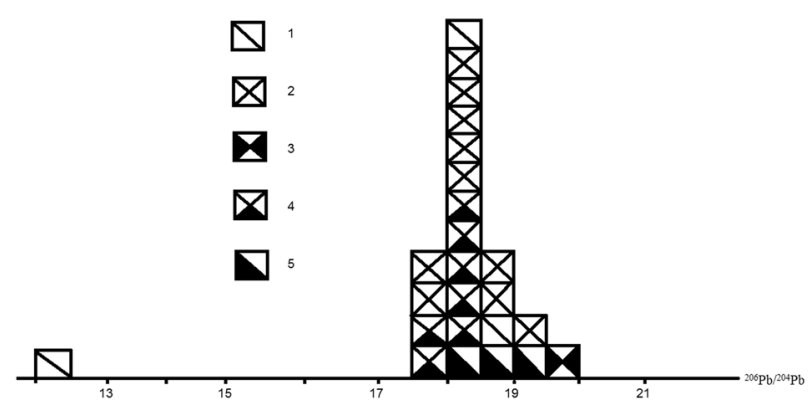

Figure 7. Histogram of ${ }^{206} \mathrm{~Pb} /{ }^{204} \mathrm{~Pb}$ of samples from the study area. 1. slate, 2. pyrrhotite from the deposit, 3 . granite, 4 . pyrite from the deposit, 5 . tetradymite from the deposit.

Lead isotope. Lead isotope results of samples collected from the study area are listed in Table 11, and further summarized in Table 12. Model lead ages in Table 11 vary significantly between $0.00 \sim 916.25 \mathrm{Ma}$, likely indicating that the lead isotopes mainly consist of more radioactive lead which is not homogeneous and thus results in strong anomalous model ages.

Figure 7 shows the components of lead in the study area. According to Zhang ${ }^{18}$, the area to the left of ${ }^{206} \mathrm{~Pb} /{ }^{204} \mathrm{~Pb}=18.5$ is generally the evolutionary area of normal lead, while to the right is the evolutionary area of anomalous leads. This confirms that lead isotopes in the study area, especially those of ore samples from the deposit, are not uniform. As a result, the model lead ages in Table 11 does not make sense geologically.

In general, the lead isotopes of pyrite are more homogeneous than that of pyrrhotite, with the least uniformity in tetradymite. This can be seen in Fig. 8, as some samples fall out of the semilunar area composed of the $\mu=10$ ( 0 time) line and the evolutionary curve, indicating that there exists anomalous lead. This further confirms that stable lead isotopes in the area are a mixture of both normal and anomalous ones.

Parent rock of the slate is mantle derived basaltic rock $\mathrm{k}^{3,5,6}$. A comparison of slate's lead isotope (series \#24 sample in Table 11) with that of material with proven origins is presented in Table 13. It can be seen that the deposit's wall rock slate is mantle derived, though post metamorphism made it deviate from the lead of pure mantle materials.

Upon synthesizing lead isotope results of slate and schist from the middle-lower Triassic ages published by former researchers in the study area (Table 14), lead isotope deviations caused by the post metamorphism become clear.

Lead isotope of the deposit's middle-lower Triassic marbles in Table 12 is similar to that of the upper crust in Table 13. Lead isotope of the lower Permian metamorphosed basalt as well as that of pyrite in the basalt are between those of the mantle and the lower crust. Likewise, lead isotope of the granite of the Indo Chinese epoch is similar to that of the upper crust, though it was possibly contaminated with the lead from the crust.

In comparison to Table 14, it can be seen that lead isotopes of the granite at the Niubeishan outside the deposit and those of the wall rocks at the deposit, including slate, schist, marble and metamorphosed basalt as well as the pyrite in the basalt, are similar to that of the post Cambrian rocks. 


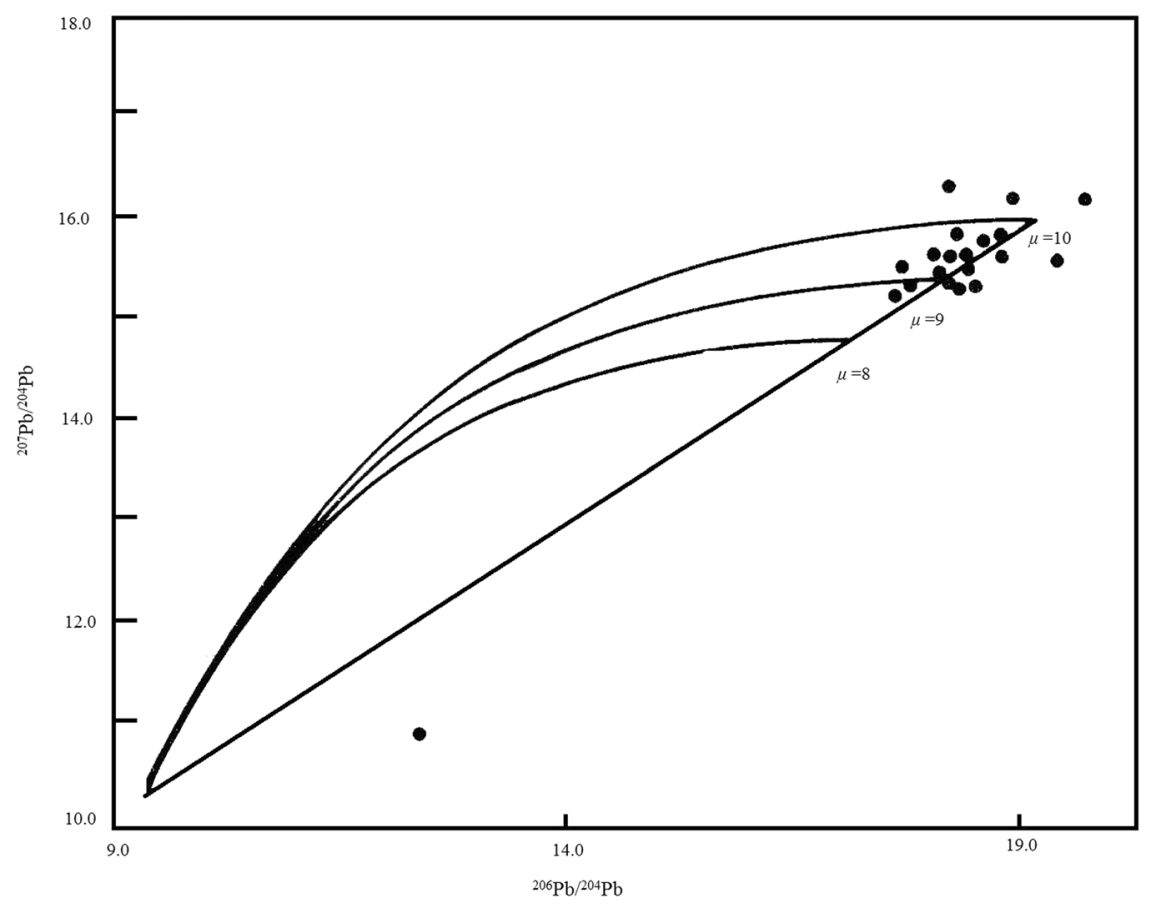

Figure 8. ${ }^{207} \mathrm{~Pb} /{ }^{204} \mathrm{~Pb}-{ }^{206} \mathrm{~Pb} /{ }^{204} \mathrm{~Pb}$ diagram of samples from the study area. (The single-stage evolution isochron and growth curve diagram of lead isotopes, part of the samples coincide with each other on the diagram).

\begin{tabular}{|l|l|l|l|}
\hline \multirow{2}{*}{ lead isotopes } & ${ }^{206} \mathbf{P b}$ & ${ }^{207} \mathbf{P b}$ & ${ }^{208} \mathbf{P b}$ \\
\cline { 2 - 4 } & ${ }^{204} \mathbf{P b}$ & ${ }^{204} \mathbf{P b}$ & ${ }^{204} \mathbf{P b}$ \\
\hline the mantle & 18.10 & 15.42 & 37.70 \\
\hline the lower crust & 17.27 & 15.29 & 38.57 \\
\hline the upper crust & 19.33 & 15.73 & 39.08 \\
\hline
\end{tabular}

Table 13. Characteristics of average lead isotopes of both the mantle \& the crust.

\begin{tabular}{|l|l|l|l|l|}
\hline & & & \multicolumn{3}{|l|}{ research area } \\
\cline { 4 - 5 } lead isotope & Precambrian* & \multirow{2}{*}{$\begin{array}{l}\text { Post- } \\
\text { cambrian* }\end{array}$} & $\begin{array}{l}\text { schist/slate at the } \\
\text { mine }\end{array}$ & $\begin{array}{l}\text { granite }\left(Y_{5}{ }^{1} \text { ) outside }\right. \\
\text { the mine }\end{array}$ \\
\hline${ }^{204} \mathrm{~Pb}$ & $>1.42 \%$ & $<1.40 \%$ & $1.371 \%(1) * *$ & $1.319 \%(1)$ \\
\hline${ }^{206} \mathrm{~Pb}$ & $<24.00 \%$ & $>24.75 \%$ & $25.248 \%(1)$ & $26.305 \%(1)$ \\
\hline${ }^{207} \mathrm{~Pb}$ & $>22.00 \%$ & $<21.50 \%$ & $21.103 \%(1)$ & $20.712 \%(1)$ \\
\hline${ }^{206} \mathrm{~Pb} /{ }^{204} \mathrm{~Pb}$ & $>17.00 \%$ & $>17.75 \%$ & $18.833 \%(3)$ & $19.947 \%(1)$ \\
\hline${ }^{208} \mathrm{~Pb} /{ }^{204} \mathrm{~Pb}$ & $>37.00 \%$ & $>37.50 \%$ & $40.202 \%(3)$ & $39.177 \%(1)$ \\
\hline${ }^{206} \mathrm{~Pb} /{ }^{207} \mathrm{~Pb}$ & $<1.19$ & $>1.14$ & $1.200(1)$ & $1.270(1)$ \\
\hline${ }^{208} \mathrm{~Pb} /{ }^{206} \mathrm{~Pb}$ & $<2.37$ & $<2.11$ & $2.070(1)$ & $1.960(1)$ \\
\hline${ }^{208} \mathrm{~Pb} /{ }^{207} \mathrm{~Pb}$ & $<2.37$ & $>2.43$ & $2.480(1)$ & $2.490(1)$ \\
\hline
\end{tabular}

Table 14. Geological time interpretation of lead isotopes of various rocks. Note *: after Zhang ${ }^{18}$, **: (number of sample, one of the results of the granite samples in the table is after Wang ${ }^{19}$.

As demonstrated in Tables 11, 12 and 13, the isotopes of pyrite and pyrrhotite of the same metallogenic epoch of the deposit are similar to each other and similar to that of the mantle, indicating that the ores' leads are derived from the mantle. Lead isotopes of the tetradymite formed in the late metallogenic epoch are both similar to and different from that of pyrite and pyrrhotite formed in the early metallogenic epoch of the deposit, implying that lead isotopes of the late metallogenic epoch are mixtures of lead from both the mantle and the crust (Fig. 9).

Table 11 clearly shows that lead isotopes of tetradymite from different ore veins are different from each other. This likely implies that: 


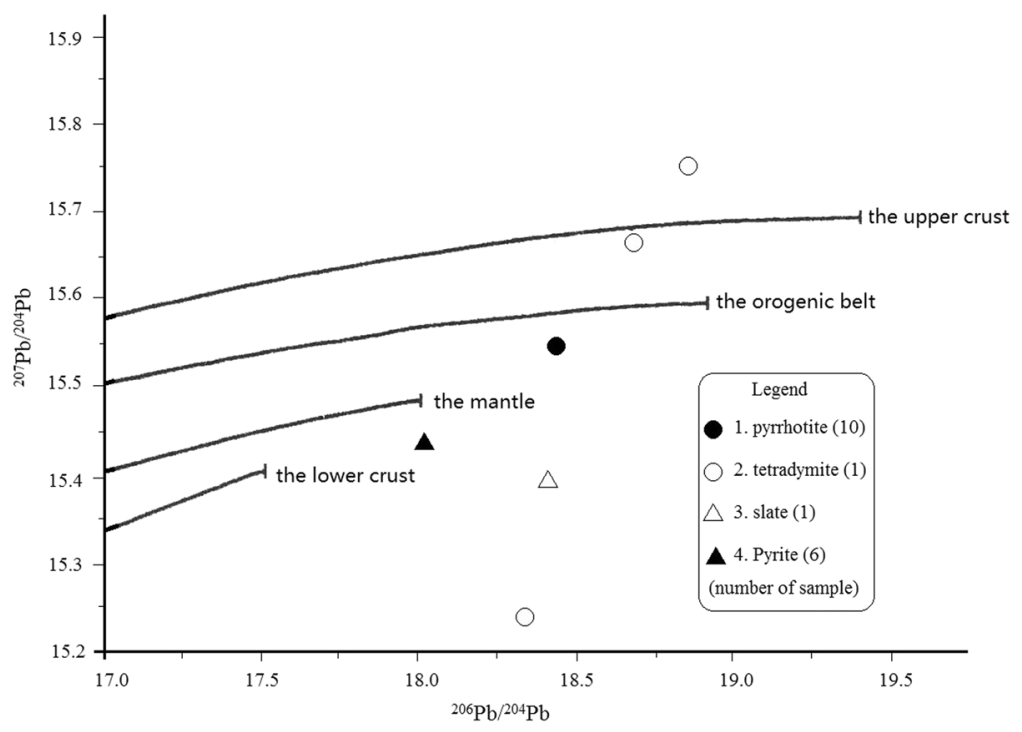

Figure 9. ${ }^{207} \mathrm{~Pb} /{ }^{204} \mathrm{~Pb}-{ }^{206} \mathrm{~Pb} /{ }^{204} \mathrm{~Pb}$ diagram of rocks/minerals from the study area.

- Emplacement of the ore bodies completed in such a short period of time that lead isotopes in the ore did not have sufficient time to homogenize;

- When quickly uplifting and emplacing, the ore bodies rose in the form of ore pulp, during which lead isotopes from the crust were captured and mixed with the original mantle derived isotopes. This means that the lead isotope compositions can be used to determine the metallogenic mechanism of mineral deposits.

It is interesting to note that lead isotope of tetradymite from Ore vein \#I-10 (series \#22 sample in Table 11) is different from that of the series \#24 sample collected at the footwall of Ore vein \#I-10 in the same table. This may further confirm that tellurium ore bodies emplaced in the form of ore magma in a very quick process, during which captured and mixed leads from both the mantle and crust and made compositions of the lead isotopes very complicated.

It can be concluded on a preliminary basis that lead isotopes of the research area consist of more radioactive lead and are very inhomogeneous. The lead isotopes of the wall rocks slate, schist and metamorphosed basalt as well as the pyrite in the basalt are mantle derived, though overlapped with characteristics of lead of the later geological events. Lead isotopes of both pyrite and pyrrhotite are close to each other and mantle derived, while that of tetradymite is different from the former, indicating that they formed in different metallogenic epochs. Lead isotope compositions reveal that tellurium ore bodies emplaced in the form of ore magma in a quick process. Finally, lead of the deposit was mainly from the mantle but also partially captured some lead from the crust.

\section{Conclusions}

- Chemical formula of the tetradymite from the Dashuigou deposit is $\mathrm{Bi}_{2.00} \mathrm{Te}_{1.89} \mathrm{~S}_{1.00}$, which contains more Te but less $\mathrm{S}$ compared to the tetradymite with a chemical formula of $\mathrm{Bi}_{2.00} \mathrm{Te}_{1.65} \mathrm{~S}_{1.35}$ on the JCPDS card in 1979, indicating that the Dashuigou tetradymite was formed in an Te-rich but S-poor environment.

- The negative values of the Dashuigou tetradymite's pyroelectricity indicate that it formed in an environment with low sulfur fugacity.

- The sulfur isotope $\delta^{34} S$ of both single sulfide minerals including tetradymite from different veins of different metallogenic epochs, and the general total sulfur isotope components of the deposit's metallogenic hydrothermal solutions, vary within a very narrow scope and a very small range close to $0.0 \%$, indicating that the deposit's sulfur is similar to that of meteorites and may be derived from the mantle.

- Lead isotopes of samples from the research area consist of more radioactive lead and are very inhomogeneous; lead isotopes of the wall rocks slate, schist and metamorphosed basalt as well as the pyrite in the basalt are mantle derived, though overlapped with characteristics of lead of the later geological events; lead isotopes of both pyrite and pyrrhotite are close to each other and mantle derived, while that of tetradymite is different from the former, demonstrating that they formed in different metallogenic epochs; lead isotope compositions reveal that tellurium ore bodies emplaced in a quick process mainly in the form of ore magma; lead of the deposit is mainly from the mantle but captured some other lead from the crust.

\section{Data availability}

The data that support the findings of this study is available from the authors upon reasonable request; see authors' contributions for specific data sets. 
Received: 30 October 2019; Accepted: 24 February 2020;

Published online: 13 March 2020

\section{References}

1. Li, T. Abundance of chemical elements in the Earth. Geochemistry, (3): 167-174 (1976, in Chinese).

2. Yin, J. et al. Introduction of tellurium resources in the world. Journal of Hebei College of Geology, 18(4): 348-354 (1995e, in Chinese).

3. Yin, J. On the metallogenic model and mineralizing mechanism of the Dashuigou independent tellurium deposit in Shimian County, Sichuan Province, China-the first and only independent tellurium deposit in the world: Chongqing Publishing House, 1394 (1996, in Chinese with English abstract).

4. Yin, J. et al. Geological characteristics of the Dashuigou tellurium deposit in Sichuan Province, China. Earth Science Frontiers 1(4), 241-243 (1994n). in Chinese.

5. Yin, J. et al. Original rock of the host rock of the Dashuigou independent tellurium deposit in Sichuan Province, China. Bulletin of Mineralogy, Petrology and Geochemistry, (2): 114-115 (1995d, in Chinese).

6. Yin, J. et al. Geology and geochemistry of host rocks of the Dashuigou independent tellurium deposit in Sichuan Province, China. Journal of Changchun University of Earth Sciences 26(3), 322-326 (1996b). in Chinese.

7. Yin, J. et al. Geology and geochemistry of altered rocks of the Dashuigou independent tellurium deposit in Sichuan Province, China. Journal of Xian College of Geology 18(4), 19-25 (1996d). in Chinese.

8. Yin, J. et al. Rock-forming minerals and ore-forming minerals of the Dashuigou tellurium ore deposit unique in the world - A preliminary study. Sci. Geol. Sinica 3(2), 197-210 (1994g).

9. Yin, J. et al. Mineralogical research of the Dashuigou independent tellurium deposit in Sichuan Province, China. Bulletin of Mineralogy, Petrology and Geochemistry, (3): 153-155 (1994k, in Chinese).

10. Berry, L.G. and Mason, B. Mineralogy. San Francisco and London, 618-630 (1959).

11. Chesterman, C.W. Field Guide to North American Rocks and Minerals. Alfred A. Knopf, New York, 831-850 (1979).

12. Bates, R.L., and Jackson J. A. (editors). Dictionary of Geological Terms. Anchor Books, A Division of Random House, Inc., New York, 520 (1984).

13. Yin, J. et al. K-Ar isotope evidence for age of the first and only independent tellurium deposit. Chinese Science Bulletin 40(22), 1933-1934 (1995a).

14. Yin, J. The metallogenic model and mineralizing mechanism of the Dashuigou independent tellurium deposit in Shimian County, Sichuan - the first and only independent tellurium deposit in the world. Acta Geoscientia Sinica, special issue: 93-97 (1996a).

15. Bayliss, Peter Crystal chemistry and crystallography of some minerals in the tetradymite group. American Mineralogist, Volume 76: 257-265(1991).

16. Cook, N. J., Ciobanu, C. L., Wagner, T. \& Stanley, C. J. Mineral of the system Bi-Te-Se-S related to the tetradymite archetype: review of classification and compositional variation. The Canadian Mineralogist ume 45, 665-708 (2007).

17. Cao, Z. and Luo, Y. Mineral sequence and ore genesis of the Sichuan telluride lode deposit in China. In: New Research Progresses of the Mineralogy, Petrology and Geochemistry in China. Lanzhou: Lanzhou University Publishing House, 476-478 (1994, in Chinese).

18. Zhang, Q. Geology and Metallogeny of the Early Precambrian in China. Changchun: Jilin People’s Publishing House, 295-297 (1984, in Chinese with English abstract).

19. Wang, X. Research on isotopes of gold mineralization at Shimian-Huili area of the Kang-Dian axis in southwest China. Mineralogy \& Petrology, 14(1): 74-82, in Chinese (1994).

\section{Acknowledgements}

Support for this study was received from both the China National Postdoctoral Foundation and from Bureau Veritas Commodities Canada Ltd., Prof. Yusheng Zhai of the China University of Geosciences in Beijing, also an Academician of the Chinese Academy of Sciences, and Prof. Rongfu Pei of the Chinese Academy of Geological Sciences, also an Academician of the Chinese Academy of Engineering in Beijing. Additional support was provided by Prof. Yuan Zhang of the College of Earth Sciences, Jilin University in Changchun of China, all of whom provided insightful discussions and critical reviews of this manuscript. The mineragraphy measurement of the tetradymite was done in the lab of the College of Earth Sciences, Jilin University. The chemical analyses by electronic probe and sulfur isotope analysis were carried out in the lab of the Chinese Academy of Geological Sciences. The X-ray diffraction analyses were carried out respectively at the lab of the Department of Earth, Ocean \& Atmospheric Sciences, the University of British Columbia, and that of the Research Center of Standard Materials, Chinese Academy of Metrological Sciences, Beijing, China. The pyroelectricity measurement was carried out in the lab of the China University of Geosciences in Beijing, China, and the lead isotope analysis was done in the lab of the Chinese Academy of Sciences in Beijing. The authors very much appreciate the time invested respectively by Peter Sean Daly, a professional technical editor/writer, M.Eng., and P.Geo. with APEGBC of Canada, and Mr. Mark Storey, M.Eng., and P.Eng. with APEGBC of Canada, for their review and editorial work on this contribution. Mr. Haoyu Yin helped generate the Fig. 1 of this paper.

\section{Author contributions}

The whole research included in the paper was proposed by the first author J.Y. The X-ray crystal powder diffraction of tetradymite was done by the second author H.S. Both authors prepared and reviewed the manuscript and approved the final version of the manuscript.

\section{Competing interests}

The authors declare no competing interests.

\section{Additional information}

Correspondence and requests for materials should be addressed to J.Y.

Reprints and permissions information is available at www.nature.com/reprints.

Publisher's note Springer Nature remains neutral with regard to jurisdictional claims in published maps and institutional affiliations. 
(c) (i) Open Access This article is licensed under a Creative Commons Attribution 4.0 International License, which permits use, sharing, adaptation, distribution and reproduction in any medium or format, as long as you give appropriate credit to the original author(s) and the source, provide a link to the Creative Commons license, and indicate if changes were made. The images or other third party material in this article are included in the article's Creative Commons license, unless indicated otherwise in a credit line to the material. If material is not included in the article's Creative Commons license and your intended use is not permitted by statutory regulation or exceeds the permitted use, you will need to obtain permission directly from the copyright holder. To view a copy of this license, visit http://creativecommons.org/licenses/by/4.0/.

(C) The Author(s) 2020 